\title{
Astragalus membranaceus (Huangqi) and Rhizoma curcumae (Ezhu) decoction suppresses colorectal cancer via downregulation of $\mathrm{Wnt} 5 / \beta$-Catenin signal
}

\author{
Yong Bian ${ }^{1 \dagger}$, Gang Wang ${ }^{1 \dagger}$, Jing Zhou ${ }^{2 \dagger}$, Gang Yin ${ }^{3}$, Tiantian Liu ${ }^{3}$, Li Liang $^{3}$, Xinyue Yang ${ }^{3}$, Wen Zhang ${ }^{4}$,
} Kexin $\mathrm{Ni}^{5}$, Decai Tang ${ }^{3^{*}}$ and Yun $\mathrm{Yu}^{5^{*}}$

\begin{abstract}
Background: The decoction of Astragalus membranaceus (Huangqi) and Rhizoma curcumae (Ezhu) has been reported as a potential antitumor agent for colorectal cancer (CRC) in experimental and clinical studies, but its underlying mechanism is still unclear.

Methods: The current research aims to explore the potential of Astragalus membranaceus (Huangqi) and Rhizoma curcumae (Ezhu) decoction (AR decoction) in the treatment of CRC and explore the underlying mechanism. SW620 cells were transient transfection to overexpress or knock down wnt 5 or $\beta$-Catenin. Astragalus membranaceus (Huangqi) and Rhizoma curcumae (Ezhu) -containing serum (AR-CS) was used to interfere with SW620 cells. Additional AR-CS, Wnt5 inhibitor (IWP-4), and $\beta$-Catenin inhibitor (JW55) were used to intervene in SW620 cells. Furthermore, subcutaneously injection of SW620 cells into the right flank of nude mice replicated xenograft mice, which were treated with AR decoction for 21 days.

Results: AR-CS significantly reduced the mRNA and protein expression levels of Wnt5, $\beta$-Catenin, ARF6, and N-Cadherin in SW620 cells, while inhibiting the proliferation and migration of SW620 cells. In cells overexpressing Wnt5 or $\beta$-Catenin, these effects of AR-CS were significantly suppressed. On the contrary, the inhibitory effect of AR-CS on the mRNA and protein levels of ARF6 and N-Cadherin and cell proliferation and migration of SW620 was enhanced, when Wnt 5 or $\beta$-Catenin were knocked down or suppressed by the inhibitors. Moreover, in the mouse model of xenograft tumors, AR decoction not only reduced the tumor volume and inhibited the mRNA levels and protein levels of Wnt5, $\beta$-Catenin, ARF6, and N-Cadherin in the tumor, but also inhibit the protein levels of LRP5, LRP6, TCF-4, and LEF1.The histopathology of mice also showed increased apoptosis in tumor tissues, and AR decoction treatment did not cause pathological damage to the kidney and liver.
\end{abstract}

\footnotetext{
*Correspondence: talknow@njucm.edu.cn; 320847@njucm.edu.cn

†Yong Bian, Gang Wang and Jing Zhou made equal contributions to this

work

${ }^{3}$ School of Traditional Chinese Medicine and School of Integrated

Chinese and Western Medicine, Nanjing University of Chinese Medicine,

Nanjing 210023, China

${ }^{5}$ School of Pharmacy, Nanjing University of Chinese Medicine,

Nanjing 210023, China

Full list of author information is available at the end of the article
}

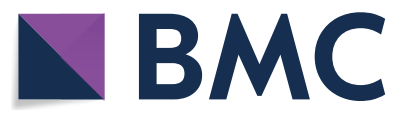

(c) The Author(s) 2022. Open Access This article is licensed under a Creative Commons Attribution 4.0 International License, which permits use, sharing, adaptation, distribution and reproduction in any medium or format, as long as you give appropriate credit to the original author(s) and the source, provide a link to the Creative Commons licence, and indicate if changes were made. The images or other third party material in this article are included in the article's Creative Commons licence, unless indicated otherwise in a credit line to the material. If material is not included in the article's Creative Commons licence and your intended use is not permitted by statutory regulation or exceeds the permitted use, you will need to obtain permission directly from the copyright holder. To view a copy of this licence, visit http://creativecommons.org/licenses/by/4.0/. The Creative Commons Public Domain Dedication waiver (http://creativeco mmons.org/publicdomain/zero/1.0/) applies to the data made available in this article, unless otherwise stated in a credit line to the data. 
Conclusions: Our results provide evidence that AR decoction inhibits Wnt5/ $\beta$-catenin signaling and inhibits the development of $C R C$, which is a promising traditional medicine in the clinical treatment of CRC.

Keywords: Astragalus membranaceus, Rhizoma curcumae, Wnt5, $\beta$-Catenin, Colorectal cancer

\section{Introduction}

Colorectal cancer (CRC), including colon cancer and rectal cancer, is the most common human digestive tract malignancy. In 2015, the incidence and mortality of CRC ranked fifth among all malignant tumors in China [1]. According to global cancer statistics in 2018, colon cancer will have become the world's third most common cancer and the second cause of tumor-related death [2, 3].

In China, traditional Chinese medicine combined with chemotherapy is part of the most important methods for the comprehensive treatment of colorectal cancer [4]. More importantly, many traditional Chinese medicine exhibit potential anticancer effect [5], including the colorectal cancer [6]. Among these Chinese herbs, it has been clear that Astragalus membranaceus (Huangqi) [7] and Rhizoma curcumae (Ezhu) [8] have antitumor effects in a variety of tumors, including lung Cancer $[9,10]$ or breast cancer $[11,12]$ etc. In clinical practice in China, Astragalus membranaceus (Huangqi) or Rhizoma curcumae (Ezhu) have been used for cancer patients, and the survival and quality of life of patients with colorectal cancer was significantly improved after treatment [13]. The decoction of Astragalus membranaceus (Huangqi) or Rhizoma curcumae (Ezhu) has also shown its potential in the treatment of colorectal cancer in experimental studies [14, 15], but its underlying mechanism is still unclear. So, the therapeutic effect of Astragalus membranaceus (Huangqi) in combination with Rhizoma curcumae (Ezhu) on colorectal cancer needs to be confirmed in more studies.

Disorders of the Wnt/ $\beta$-catenin signaling pathway are widely present in different types of malignant tumors, and are particularly significant in digestive system tumors [16]. In colorectal cancer, about $80 \%$ of patients have abnormal activation of the Wnt pathway [17]. The Wnt/ $\beta$-Catenin signaling pathway promotes the abnormal proliferation of intestinal epithelial cells, the disappearance of normal intestinal wall structure, and ultimately leads to the occurrence of CRC $[18,19]$. Hyperactivation of Wnt signal promotes the transfer of $\beta$-catenin from the cytoplasm to the nucleus and accelerates the process of transforming benign colon tumors to malignant tumors [20]. The Wnt/ $\beta$-catenin signaling pathway and its related factors have become diagnostic and prognostic indicators of gastrointestinal tumors [21, 22]. Therefore, Targeting Wnt/ $\beta$-catenin to treat CRC has emerged as a therapeutic strategy and been continuously concerned by researchers [23].

In this study, we explored the potential of Astragalus membranaceus (Huangqi) in combination with Rhizoma curcumae (Ezhu) decoction (AR decoction) in the treatment of CRC. First, the rat Astragalus membranaceus (Huangqi) and Rhizoma curcumae (Ezhu)-containing serum (AR-CS) was used in vitro to evaluate the inhibitory effects of Astragalus membranaceus (Huangqi) and Rhizoma curcumae (Ezhu) on the proliferation and migration of colorectal cancer cells. Further, we provided the evidence for its treatment of CRC by inhibiting Wnt/ $\beta$-catenin signaling in vitro. Importantly, AR decoction could inhibit tumor growth and inhibit $\mathrm{Wnt} / \beta$-catenin signaling in mouse models of CRC xenograft tumors.

\section{Materials and methods Reagents}

IWP-4 (\#HY-12879) and JW55 (\#HY-13968) were purchased from MedChemExpress (New Jersey, USA). CCK8 kit (\#CA1210), 4\% paraformaldehyde (\#P1110), hematoxylin-eosin staining kit (\#G1120), Trizol(\#R1100), BCA Protein Quantitative Kit (\#PC0020), and 30\% acrylamide (29:1) (\#A1010) were purchased from Solarbio life sciences (Beijing, China). HiFiScript gDNA Removal RT MasterMix (\#CW2020) and SuperRT One Step RT-PCR Kit (\#CW0742) were purchased from cwbiosciences (Jiangsu, China). Protein loading buffer (\#P0015L), protein pre-staining Marker(\#P0069), and BeyoECL Star Luminescent Liquid (\#P0018AS) were purchased from Beyotime (Shanghai, China). Cr(C011-2-1), BUN (C0132-1), AST (C010-2-1), and ALT(C009-2-1), detection kits were purchased from Nanjing Jiancheng Bioengineering Institue (Nanjing, Chian). Antibody for Wnt5 (\#55184-1AP), $\beta$-Catenin (\#51067-2-AP), ARF6 (\#20225-1-AP), and N-Cadherin (\#22018-1-AP), and GAPDH (\#60004-1-Ig), HRP-conjugated Affinipure Goat Anti-Rabbit IgG(H+L) (\#SA00001-2), and FITC-conjugated Affinipure Goat Anti-Rabbit IgG(H+L) (\#SA00003-2) were purchased from Proteintech (Wuhan, China). Antibody for LRP5 (ab223203), LRP6 (ab134146), TCF-4 (ab130014), and LEF1 (ab137872) were purchased from abcam (Cambridge, UK).

\section{Drugs and drug-containing serum preparation \\ Astragalus membranaceus (Huangqi) and Rhizoma cur-} cumae (Ezhu) were purchased from China Traditional 
Chinese Medicine Co., Ltd. AR decoction are obtained by soaking the traditional Chinese medicine Astragalus membranaceus (Huangqi) and Rhizoma (Ezhu) curcumae decoction with traditional water decoction [24]. Astragalus membranaceus (Huangqi) (500 g) and Rhizoma curcumae (Ezhu) (500 g) were weighed and added to a stainless pot. After $2 \mathrm{l}$ water added and boiled for $1 \mathrm{~h}$, the liquid was collected. Then $2 \mathrm{l}$ water is added and boiled for another $1 \mathrm{~h}$ to collect liquid again. The solution that was combined twice, a rotary evaporator was used to concentrate the solution and the final volume was concentrated to $500 \mathrm{ml}$. The concentration of Astragalus membranaceus (Huangqi) and Rhizoma curcumae (Ezhu) is (1 g Astragalus membranaceus (Huangqi) $+1 \mathrm{~g}$ Rhizoma curcumae (Ezhu))/ml. The clinical dosage of Astragalus membranaceus and Rhizoma curcumae is $(25 \mathrm{~g}+25 \mathrm{~g}) /$ day. Based on the conversion method drove from body surface coefficient of mice (Body surface area ratio of mice and humans $=0.0026$ ) or rat (Body surface area ratio of rat and humans $=0.018$ ) and human. The dose for mice is $6.5 \mathrm{~g} / \mathrm{kg}$, the dose for rats is $4.5 \mathrm{~g} / \mathrm{kg}$. They were calculated as follows: Mice: $50 \mathrm{~g} /$ day (human dosage $)^{*} 0.0026 / 0.02 \mathrm{~kg}($ weight of mice $)=6.5 \mathrm{~g} / \mathrm{kg} /$ day. Rat: $50 \mathrm{~g} /$ day (human dosage)*0.018/0.2 $\mathrm{kg}$ (weight of rat $)=4.5 \mathrm{~g} / \mathrm{kg} /$ day.

All procedures of animals described in this study were performed in accordance to the guidelines of the Institutional Animal Ethical Committee of Nanjing University of Chinese Medicine and in accordance with the ethical standards established by Ethics Committee of Nanjing University of Chinese Medicine. Forty male SD rats with SPF grade, 12 weeks old, weighing 250-280 g, were housed in a standard SPF animal feeding center (with temperature $20-26{ }^{\circ} \mathrm{C}$, humidity $40-70 \%$, and 12 -h day/ night light cycle). After a week of adaptation, 20 of the rats were intragastric administration with AR decoction $(4.5 \mathrm{~g} / \mathrm{kg})$ for seven consecutive days. Other 20 rats were intragastric administration with water. After seven days, these rats were deeply anesthetized and blood was taken from the common intracranial artery into the procoagulation tube [25]. Each rat could obtain about $10 \mathrm{ml}$ of whole blood. After centrifugation (3000 rpm, $10 \mathrm{~min}$ ), the serum of the rats in the same group was collected and mixed. At least $100 \mathrm{ml}$ AR-CS and $100 \mathrm{ml}$ normal rat serum were obtained.

\section{Quality control of drugs and drug-containing serum}

The content of representative substances in AR decoction and AR-CS was determined by Agilent 1260 high performance liquid chromatograph HPLC (Agilent, USA). The chromatographic column is a Hedera ODS-2 C18 chromatographic column $(4.6 \mathrm{~mm} \times 250 \mathrm{~mm}$, $5 \mu \mathrm{m}$, Jiangsu Hanbang Technology Co., Ltd.).
Methanol-0.1\% phosphoric acid aqueous solution (A: B) was used as mobile phase, gradient elution, elution time and mobile phase ratio are shown in Table 1. Flow rate was $1.0 \mathrm{ml} / \mathrm{min}$, injection volume was $20 \mu \mathrm{l}$, column temperature was $30{ }^{\circ} \mathrm{C}$, Full-wavelength scanning, extraction wavelengths were 215 and $420 \mathrm{~nm}$.

Sample pretreatment: For AR decoction, $1 \mathrm{ml}$ of extract was accurately drawn and add $1 \mathrm{ml}$ of absolute ethanol. After mixing, it was standed for $24 \mathrm{~h}$, centrifuged at 13,000 rpm for $10 \mathrm{~min}$. Then the supernatant was taken, and passed through $0.22 \mu \mathrm{m}$ filter membrane. And the sample was injected.

For AR-CS: $400 \mu \mathrm{l}$ of serum was precisely aspirated, precisely added $1.6 \mathrm{ml}$ of methanol, extracted with ultrasound for $10 \mathrm{~min}$, centrifuged at $13,000 \mathrm{rpm}$ for $10 \mathrm{~min}$. Then $1.8 \mathrm{ml}$ of the supernatant was precisely aspirated, blowed dry with $\mathrm{N} 2$, and added $100 \mu \mathrm{l}$ of methanol-0.1\% phosphoric acid aqueous solution (20:80) for redissolve, centrifuged at 13,000 rpm for $10 \mathrm{~min}$, and the supernatant was taken for injection.

Nine main components in AR extract were quantitatively detected by HPLC, among which the maximum absorption wavelength of Calycosin-7-glucoside (CAS: 20633-67-4), Ononin (CAS: 486-62-4), Calycosin (CAS: 20575-57-9), Kaempferol (CAS: 520-18-3), Formononetin (CAS: 485-72-3), Curdion (CAS: 13657-68-6), Curzerene (CAS: 17910-09-7), and Isocurcumenol (CAS: 24063-71-6) were $215 \mathrm{~nm}$. The contents in the extract were $0.08,0.05,0.04,0.03,0.02,0.03,0.02 \mathrm{mg} /$ $\mathrm{ml}$, and the contents in the serum of rats were 0.79 , $2.09,1.01,1.26,1.07,2.06,0.77,0.81 \mu \mathrm{g} / \mathrm{ml}$, respectively. The maximum absorption wavelength of curcumin was $420 \mathrm{~nm}$, and the content of curcumin in extract and serum after administration were $0.01 \mathrm{mg} /$ $\mathrm{ml}$ and $0.68 \mu \mathrm{g} / \mathrm{ml}$, respectively. The results are shown in Fig. 1 and Table 2. All the standard substances (purity $>98 \%$ ) were purchased from National Institute of Metrology (Beijing, China).

Table 1 Methanol-0.1\% phosphoric acid aqueous solution mobile phase elution time and solution ratio

\begin{tabular}{lll}
\hline Time & A (V/V \%) & B (V/V \%) \\
\hline 0 & 10 & 90 \\
4 & 20 & 80 \\
6 & 25 & 75 \\
15 & 30 & 70 \\
30 & 40 & 60 \\
50 & 70 & 30 \\
70 & 70 & 30 \\
\hline
\end{tabular}


A

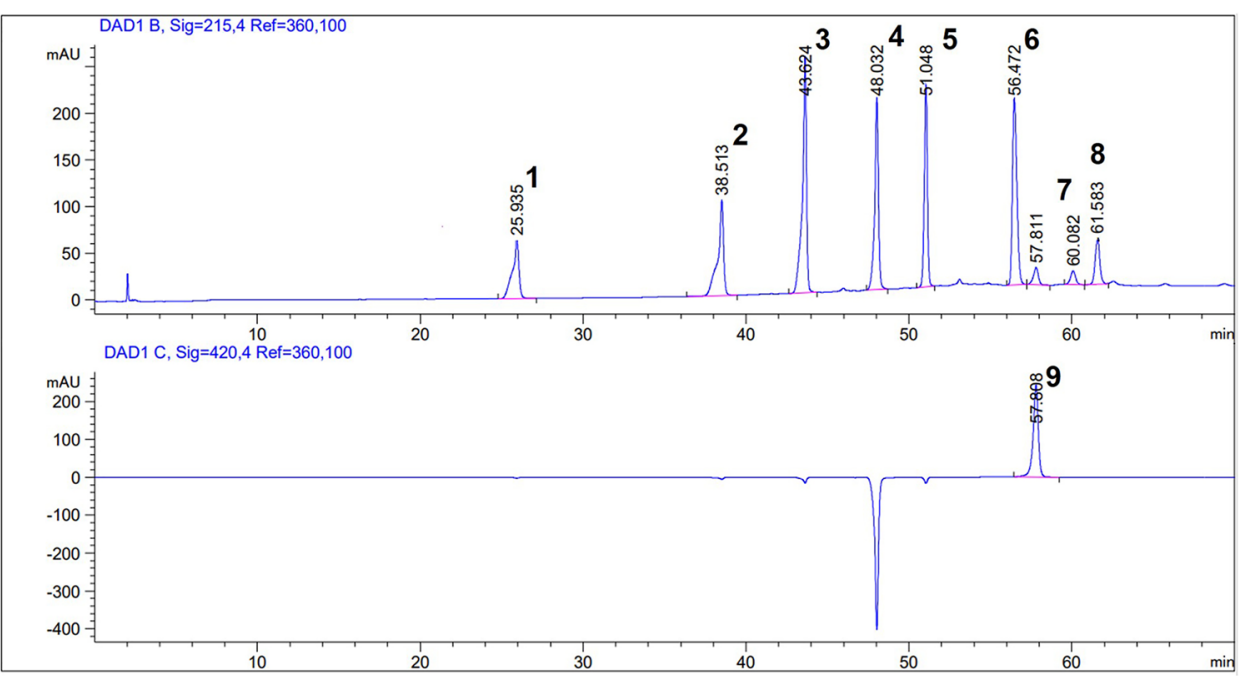

B

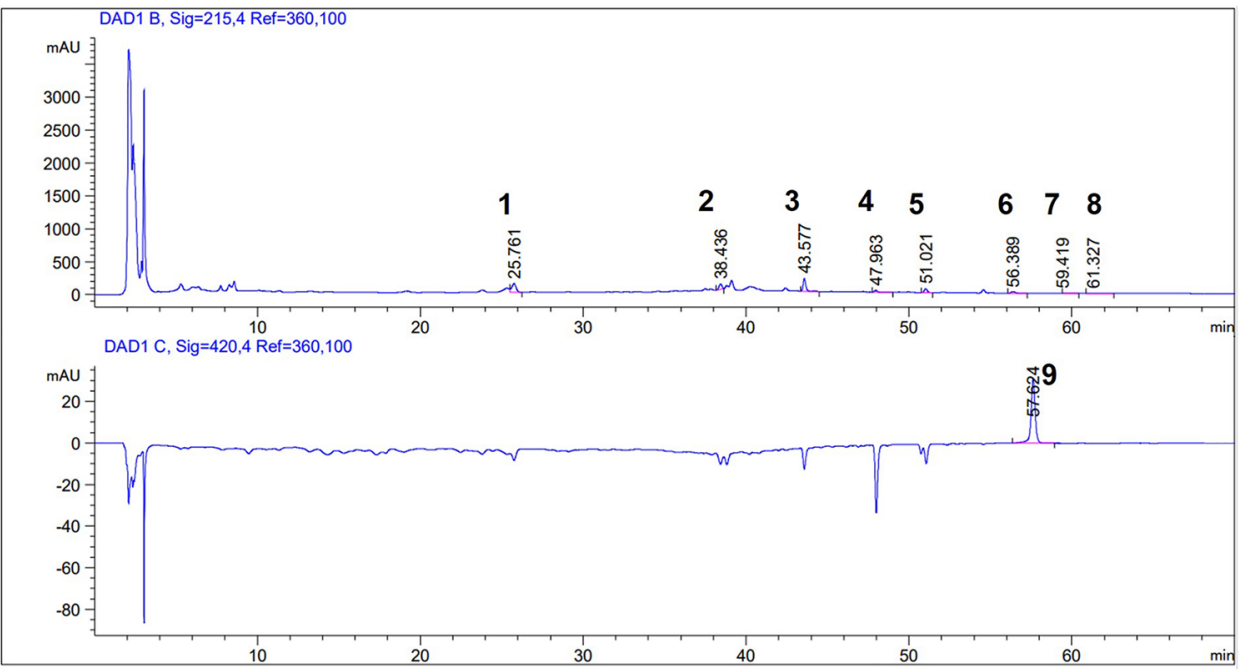

C

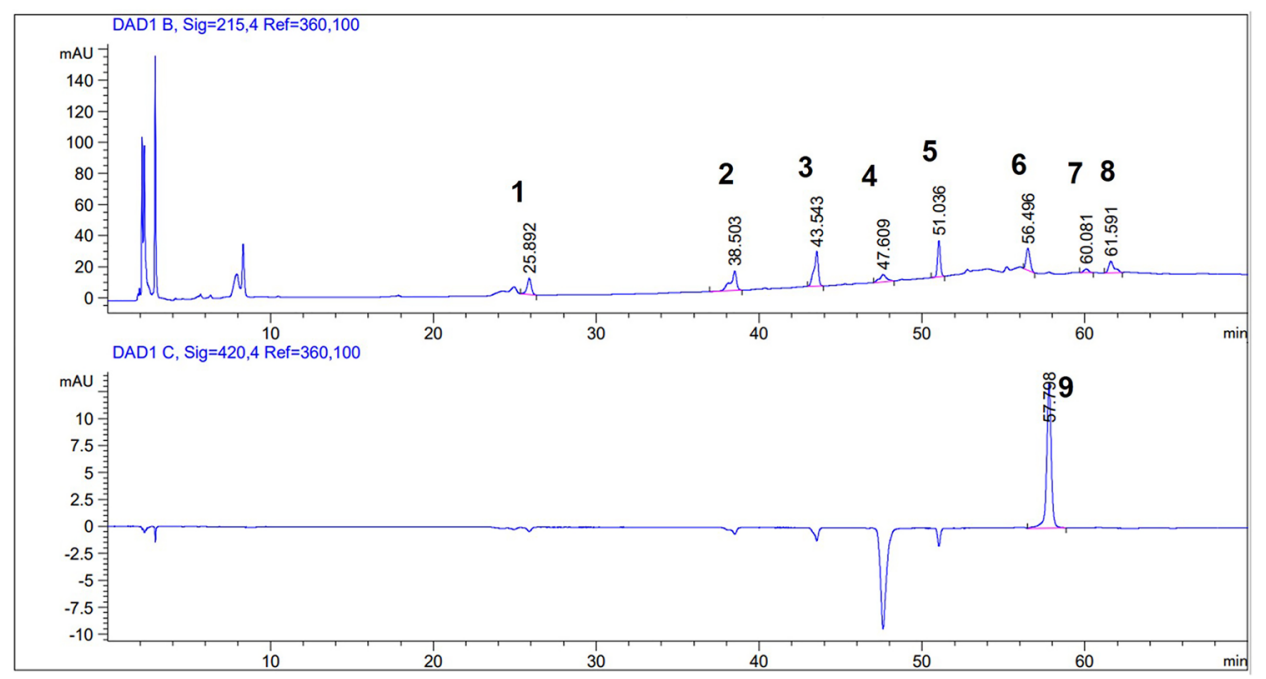

Fig. 1 Representative HPLC chromatograms of AR decoction and AR-CS. Representative HPLC chromatograms of standard substance mixture (A), AR decoction (B), and AR-CS (C) showed retention peaks of nine substances. They were 1: Calycosin-7-glucoside, 2: Ononin, 3: Calycosin, 4: Kaempferol, 5: Formononetin, 6: Curdion, 7: Curzerene, 8: Isocurcumenol, and 9 curcumin 
Table 2 Content of 9 compounds in AR decoction and AR-CS

\begin{tabular}{|c|c|c|c|c|c|c|c|}
\hline \multirow[t]{2}{*}{ Name } & \multirow[t]{2}{*}{ Wave (nm) } & \multicolumn{2}{|c|}{ Standard solution } & \multicolumn{2}{|c|}{ AR decoction } & \multicolumn{2}{|l|}{ AR-CS } \\
\hline & & $\begin{array}{l}\text { RT } \\
\min \end{array}$ & $\begin{array}{l}\text { Content } \\
\mathrm{mg} / \mathrm{ml}\end{array}$ & $\begin{array}{l}\text { RT } \\
\min \end{array}$ & $\begin{array}{l}\text { Content } \\
\mathrm{mg} / \mathrm{ml}\end{array}$ & $\begin{array}{l}\text { RT } \\
\min \end{array}$ & $\begin{array}{l}\text { Content } \\
\mu \mathrm{g} / \mathrm{ml}\end{array}$ \\
\hline Calycosin-7-glucoside & 215 & 25.935 & 0.04 & 25.761 & 0.08 & 25.892 & 0.79 \\
\hline Ononin & 215 & 38.513 & 0.06 & 38.436 & 0.05 & 38.503 & 2.09 \\
\hline Calycosin & 215 & 43.624 & 0.04 & 43.577 & 0.04 & 43.543 & 1.01 \\
\hline Kaempferol & 215 & 48.032 & 0.11 & 47.963 & 0.03 & 47.609 & 1.26 \\
\hline Formononetin & 215 & 51.048 & 0.04 & 51.021 & 0.02 & 51.036 & 1.07 \\
\hline Curdion & 215 & 56.472 & 0.12 & 56.389 & 0.03 & 56.496 & 2.06 \\
\hline Curzerene & 215 & 60.082 & 0.02 & 60.019 & 0.02 & 60.081 & 0.77 \\
\hline d Isocurcumenol & 215 & 61.583 & 0.03 & 61.327 & 0.02 & 61.591 & 0.81 \\
\hline curcumin & 420 & 57.808 & 0.05 & 57.624 & 0.01 & 57.798 & 0.68 \\
\hline
\end{tabular}

$\mathrm{RT}$, retention time

\section{Cell culture and transient transfection}

SW620 cell line was purchased from ATCC. SW620 cells were cultured with DMEM (\#06-1170-87-1A, Biological Industries, Israel) containing $10 \%$ fetal bovine serum (\#04-011-1A, Biological Industries, Israel), $100 \mathrm{U} / \mathrm{ml}$ penicillin and $100 \mathrm{mg} / \mathrm{mL}$ streptomycin (\#03-034-1B, Biological Industries, Israel). SW620 cells were incubated in a cell incubator (Thermo Scientific, USA) containing $5 \% \mathrm{CO}_{2}$, at $37^{\circ} \mathrm{C}$.

Wnt 5 (\#sc-41112) and $\beta$-catenin (\#sc-29209) siRNA and control (\#sc-37007) siRNA were purchased from Santa Cruz Biotechnology (CA, USA). pcDNA-Wnt 5 and pcDNA- $\beta$-catenin and control vector were purchased from Addgene (Cambridge, UK). SW620 cells were cultured in DMEM medium at a density of $10^{5}$ cells in 6-well plates. According to the manufacturer's instructions, lipofectamine 3000 reagent (\#L3000015, Invitrogen, CA, USA), pcDNA-Wnt 5 ( $2 \mu \mathrm{g})$, pcDNA- $\beta$-catenin $(2 \mu \mathrm{g})$, control vector $(2 \mu \mathrm{g})$ or wnt 5 siRNA, $\beta$-catenin siRNA (50 $\mathrm{nM})$ and control siRNA (50 $\mathrm{nM}$ ) were used to transiently transfect into cells. After $6 \mathrm{~h}$ of transfection, complete culture medium was added to the transfection medium, continue culturing for $12 \mathrm{~h}$. Then the cells are collected for inoculation.

\section{CCK-8 assay}

Cell Count Kit-8 (CCK-8) was used to test cell viability. The current research conducted multiple cell viability tests, including Sw620 cells were treated with different concentrations of AR solution for $12 \mathrm{~h}$, and SW620 cells were treated with different concentrations of FBS or rat serum for $12 \mathrm{~h}$. Different concentrations of AR-CS $(0 \%$, $20 \%, 40 \%, 80 \%, 100 \%$ ) were used to incubate SW620 cells for $12 \mathrm{~h}$, or $20 \%$ AR-CS treated SW620 cells for different administration time $(0 \mathrm{~h}, 3 \mathrm{~h}, 6 \mathrm{~h}, 9 \mathrm{~h}, 12 \mathrm{~h}, 18 \mathrm{~h}, 24 \mathrm{~h})$ were another two independent experiments. When different concentrations of AR-CS $(0 \%, 20 \%, 10 \%, 5 \%)$ were used on SW620 cells for $24 \mathrm{~h}$, diffferent concentrations of blank rat serum $(20 \%, 0 \%, 10 \%, 15 \%)$ were added to make the serum concentration to $20 \%$ in all groups.

For cell viability detection, SW620 cells were seeded at a density of 5000 cells/well in 96 -well plates. After the cells adhered, different concentrations of drug-containing serum were added to SW620 cells for different time. $10 \mu \mathrm{l}$ of CCK-8 reagent was added to the 96-well plate $2 \mathrm{~h}$ before the termination of the experiment. After two hours, microplate reader was used to determine the absorbance (OD) value at a wavelength of $450 \mathrm{~nm}$. The cell viability of the control group was defined as $100 \%$, and the cell viability was calculated according to the formula: Cell viability $=(O D$ of test group/Everage OD of control group)* $100 \%$.

\section{Transwell assay}

The current study performed four Transwell assays. The treatment of SW620 cells in these four cell experiments is different. In the first experiment, different concentrations of AR-CS $(0 \%, 20 \%, 10 \%, 5 \%)$ treated SW620 cells for $24 \mathrm{~h}$. In the second experiment, WT, Wnt5 overexpressed, and $\beta$-Catenin over-expressed SW620 cells with or without $20 \%$ AR-CS treated for $12 \mathrm{~h}$. In the third experiment, WT, Wnt5 knock-down, and $\beta$-Catenin knock-down SW620 cells with or without 20\% AR-CS treated for $24 \mathrm{~h}$. In the fourth test, SW620 cells were treated with or without $20 \%$ AR-CS, Wnt5 inhibitor (IWP-4), and $\beta$-Catenin inhibitor (JW55) treated for $24 \mathrm{~h}$.

Briefly, WT, Wnt5 over-expressed, $\beta$-Catenin overexpressed, Wnt5 knock-down, or $\beta$-Catenin knock-down cells are digested and seeded into the upper chamber of 
the Transwell chamber. After adherent, cells were incubated with AR-CS and tool drugs for the corresponding time. Subsequently, the cells on the upper chamber were fixed and stained with crystal violet. The cells inside the inner membrane of the chamber were erased, and the number of cells on the underside of the membrane placed on the glass slide was observed with an inverted optical microscope. Then the pictures were taken. The cell migration rate of the normal group was defined as $100 \%$, and the overall migration rate of the other groups was calculated. The calculation formula for the migration rate is: migration rate $=$ (number of test group/Average number of control group)*100\%.

\section{Wound scratch assay}

Like the Transwell experiment, the wound scratch assay also tested the wound healing rate under four different conditions. Briefly, WT, Wnt5 over-expressed, $\beta$-Catenin over-expressed, Wnt5 knock-down, or $\beta$-Catenin knockdown cells were seeded into 24-well plates after digestion. After the cells adhere to the wall, a scratch needle was used to slightly scratch along the blank center axis. After cleaning once, pictures were taken by an inverted optical microscope, and the scratch area (Area 1) was calculated. The cells were incubated with AR-CS and tool drugs for the corresponding time. Then the cells were fixed and washed. The healing of the scratches was observed under an inverted optical microscope, and the area of the scratches (Area 2) was calculated. The wound healing rate is calculated by the following formula: wound healing rate $=($ Area $1-$ Area 2$) /$ Area $1 * 100 \%$.

\section{Immunocytofluorescent staining}

Briefly, WT, Wnt5 over-expressed, $\beta$-Catenin overexpressed, Wnt5 knock-down, or $\beta$-Catenin knock-down cells were seeded into 24-well plates with glass coverslips. After the cells adhere to the coverslips, different concentrations of drug-containing serum were added to SW620 cells for different time. After that, the cells were fixed with $4 \%$ paraformaldehyde. PBS was used to clean and $\beta$-Catenin (1:100) was used to incubate the cells for overnight. FITC-conjugated goat anti-rabbit IgG (1:100) was used to incubate the cells for $1 \mathrm{~h}$, and then DAPI was used to stain the cells for $5 \mathrm{~min}$. Photographs were taken with a fluorescence microscope after glycerin gelatin was used to seal the coverslips on glass slides.

\section{Real time qPCR}

The treatment of cells was the same as in the Transwell assay. A total of four different cell treatments were carried out. For collected SW620 cells or tumor tissues derived from xenograft mice, after using Trzol reagent to extract total RNA, the mRNA of SW620 cells or tumor tissues was reverse transcribed into cDNA, referring to the instruction. After referring to the PCR reaction kit instructions, the mRNA expression levels of Wnt5, $\beta$-Catenin, ARF6, and N-Cadherin were measured by the ABI7500 system. GAPDH(\#B661104) primer was purchased from Sangon Biotech (Shanghai, China). The other primers were synthesized by Sangon Biotech (Shanghai, China), the sequences were as follows:

Wnt5: forward: CCTGAAGGAGAAGTACGACAG, reverse: GATGTAGACCAGGTCTTGTGTG, product size: $112 \mathrm{bp}$.

$\beta$-Catenin: forward: TGGATTGATTCGAAATCTTGCC, reverse: GAACAAGCAACTGAACTAGTCG, product size: $92 \mathrm{bp}$.

ARF6: forward: GC T C TG GCG GCA T TA CTA CACTG,reverse: AGGATTATGGCGTCCCTCATCTCC, product size: $138 \mathrm{bp}$.

N-Cadherin: for ward: CGATAAGGATCAACCCCA TACA, reverse: TTCAAAGTCGATTGGTTTGACC, product size: $142 \mathrm{bp}$.

The $2^{-\Delta \Delta}$ method was used to calculate the relative expression levels of Wnt5, $\beta$-Catenin, ARF6, and N-Cadherin mRNA in SW620 cells or tumor tissues.

\section{Western blot}

The treatment of cells was the same as in the Transwell assay. A total of four different cell treatments were carried out. For the collected SW620 cells or tumor tissues derived from xenograft mice, after using the REPI lysate to extract the total protein, the total protein level of SW620 cells or tumor tissues was determined, referring to the $\mathrm{BCA}$ protein determination kit instruction. After each sample was boiled with the loading buffer, the protein was separated by SDS-PAGE gel electrophoresis. After transferring the protein in the gel to the PVDF membrane, the PVDF membrane was incubated with Wnt5, $\beta$-Catenin, ARF6, N-Cadherin, LRP5, LRP6, TCF4 , and LEF1 and GAPDH overnight at $4{ }^{\circ} \mathrm{C}$. After that, the PVDF membrane was incubated with HRP-modified goat anti-rabbit Igg for $2 \mathrm{~h}$. After washing, the highsensitivity chemiluminescence solution combined with the gel imaging system was used to visualize the blots of Wnt5, $\beta$-Catenin, ARF6, N-Cadherin, LRP5, LRP6, TCF4, LEF1, and GAPDH in SW620 cells or tumor tissues.

\section{Xenograft tumor models}

Fifteen nude mice with SPF grade were 6 weeks old, weighing $18-22 \mathrm{~g}$. And $2 \times 10^{6}$ SW620 cells were subcutaneously injected into the right flank of nude mice. After the cells were injected. The animals were divided into three groups: the model group, the AR treatment group and the oxaliplatin treatment group, each group contained 5 mice. AR decoction $(6.5 \mathrm{mg} / \mathrm{kg})$ was 
given by gavage daily for 21 days. Oxaliplatin $(1 \mathrm{mg} /$ $\mathrm{kg}$ ) was used as a positive drug and was administered by intrapulmonary injection every day for 21 consecutive days. As a model control, mice were given water by gavage every day. The mice are weighed every 2 days. The length and width of the tumor were measured every three days and the volume of the tumor was calculated as length $\times$ width $^{2}$. After 21 days, the mice were sacrificed and the tumor tissues were taken out, and the tumors were photographed and weighed.

\section{Hematoxylin-eosin (HE) staining}

After the mice were treated, they were sacrificed and tumor tissues were obtained. The tumor mass of each mouse was incised from the middle. Half was used for the above-mentioned WB experiment, and the other half was immersed in paraformaldehyde. At the same time, the liver and kidney of mice were fixed in paraformaldehyde. Tumors, livers and kidneys from mice were coated into wax blocks after routine dehydration, transparency and wax immersion treatments. Then HE staining was performed and photographed by an ordinary light microscope. The experimental procedures of tissue embedding, sectioning and HE staining refer to the previous report [26].

\section{Blood biochemical test}

After the mice were treated, they were sacrificed and serum was obtained. The levels of Cr, BUN, AST, and ALT in serum were detected according to the kit manufacturer's instructions.

\section{Statistical analysis}

Statistical analysis was carried out using ANOVA. Results are expressed as mean $\pm \mathrm{SD}$. $\mathrm{p}<0.05$ was considered as a significant difference. All analyses were performed with GraphPad Prism Version 5.01 (GraphPad Software Inc., San Diego, CA, USA).

\section{Results}

\section{AR-CS inhibits the proliferation and migration of SW620}

cells

Different concentrations of AR decoction (0.1, 0.2, 0.4, $0.8,1.6,3.2,6.4 \mathrm{~g} / \mathrm{ml}$ ) were used to incubate SW620 cells for $12 \mathrm{~h}$, the cell viability results showed that AR decoction $(0.1-6.4 \mathrm{~g} / \mathrm{ml})$ had a significant inhibitory effect in SW620 cells cultured with 10\%FBS- containing medium (Fig. 2A). Different concentrations of FBS (1\%, 10\%) or rat serum (RS) $(5 \%, 10 \%, 20 \%)$ treatment showed that the serum concentration had significant positive-going impact on the cell viability in SW620 cells (Fig. 2A). In order to exclude the influence of serum on experimental results, blank rat serum was used in all subsequent experiments to adjust the serum concentration of $20 \%$ in all group.

SW620 cells were treated with increasing concentrations of AR-CS $(0 \%, 20 \%, 40 \%, 80 \%, 100 \%)$ for $12 \mathrm{~h}$, and the cell viability was detected. After $20 \%$ AR-CS was applied to SW620 cells for $12 \mathrm{~h}$, the cell viability was approximately $60-70 \%$ (Fig. 2C). Then $20 \%$ of AR-CS was used on SW620 cells for different time $(0 \mathrm{~h}, 3 \mathrm{~h}, 6 \mathrm{~h}$, $9 \mathrm{~h}, 12 \mathrm{~h}, 18 \mathrm{~h}, 24 \mathrm{~h}$ ). With the increase of the time, the cell activity continued to decrease, and the cell activity was about $70 \%$ after $12 \mathrm{~h}$ of treatment, about $60 \%$ after 24 h (Fig. 2D). A 20\% / 10\% / 5\% gradient concentration of AR-CS was selected to act on SW620 cells for $24 \mathrm{~h}$ to observe cell viability again. The results showed that AR-CS concentration-dependently reduced the viability of SW620 cells (Fig. 2E). Transwell assay and wound scratch assay showed that cell migration rate and wound healing rate were also reduced in a concentrationdependent manner by AR-CS (Fig. 2F-I).

\section{AR-CS inhibits Wnt/ $\beta$-Catenin signaling of SW620 cells}

After observing that AR-CS has the ability to inhibit the proliferation and migration of colorectal cancer cells, we tried to find the possible mechanism behind this. We focus on the Wnt/ $\beta$-Catenin signaling. After 20\% / 10\% / $5 \%$ gradient concentration of AR-CS acted on SW620 cells for $24 \mathrm{~h}$, Wnt 5 and $\beta$-Catenin mRNA levels and protein levels in SW620 cells were significantly reduced (Fig. 3A, B, E-G). $\beta$-Catenin was retested using immunofluorescence, and the results showed AR-CS significantly reduced the fluorescence intensity of $\beta$-Catenin in SW620 cells (Fig. 3H, I). Furthermore, we detected the expression of ARF6 and N-Cadherin, which are related to tumor cell proliferation, adhesion and migration ability. After the application of AR-CS, the results showed that the $20 \% / 10 \% / 5 \%$ gradient concentration of AR-CS significantly reduced the mRNA level and protein level of ARF6 and N-Cadherin after $24 \mathrm{~h}$ in SW620 cells (Fig. 3C, D, J-L).

\section{Overexpression of Wnt 5 or $\beta$-Catenin eliminates the inhibition ability of AR-CS in proliferation and migration of SW620 cells}

To determine whether the inhibition of $\mathrm{Wnt} / \beta$-Catenin signaling is the potential cause of AR-CS to inhibit the proliferation and migration of SW620 cells, the Wnt 5 or $\beta$-Catenin overexpression plasmids was used to temporarily increased the mRNA level of Wnt 5 or $\beta$-Catenin in SW620 cells (Fig. 4A, B). The results of western blot showed that overexpression of Wnt 5 or $\beta$-Catenin promoted an increase in the protein level of Wnt 5 or $\beta$-Catenin in SW620 cells (Fig. 4E, G, H). Compared with WT-type SW620, overexpression of 


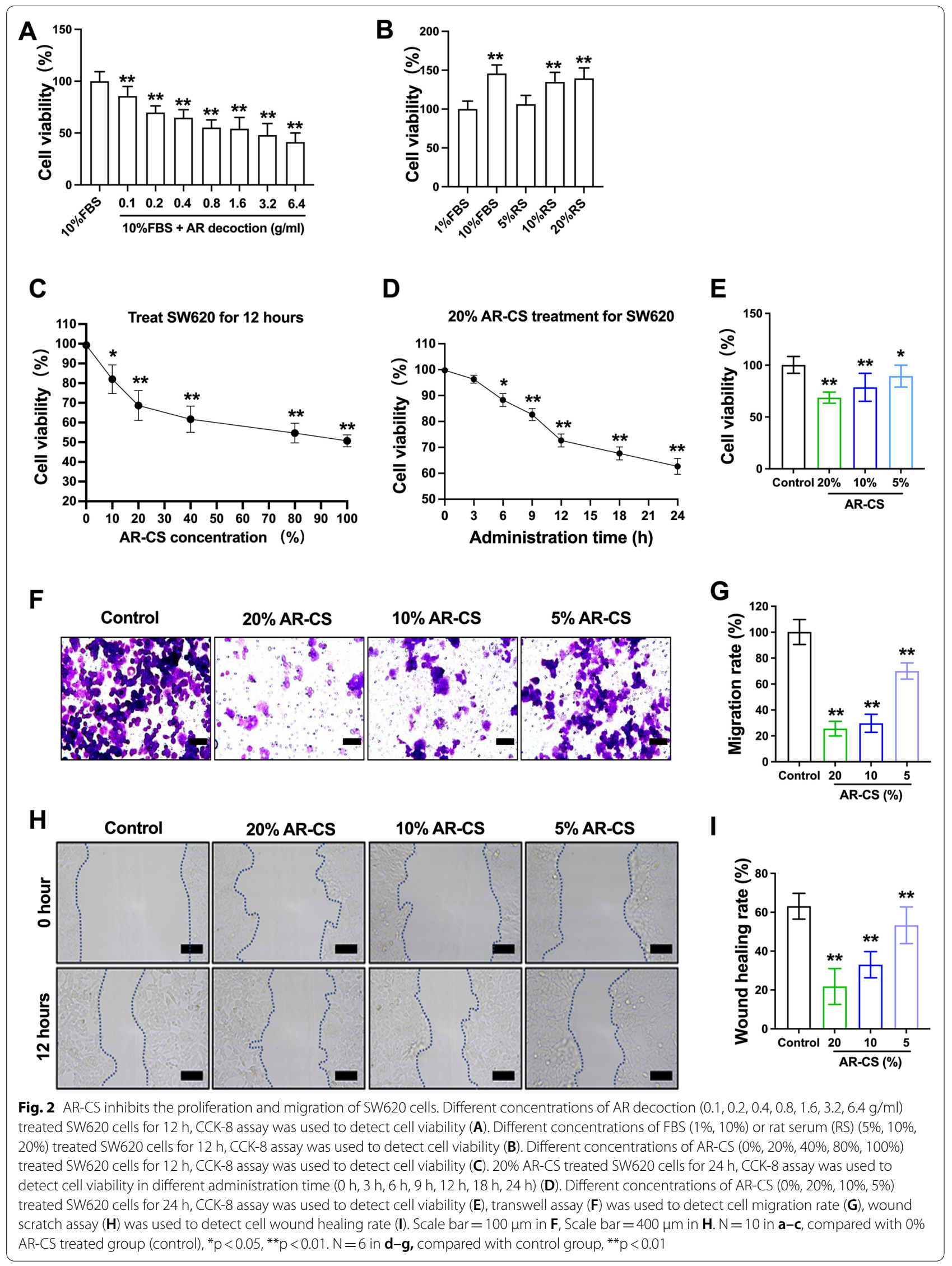



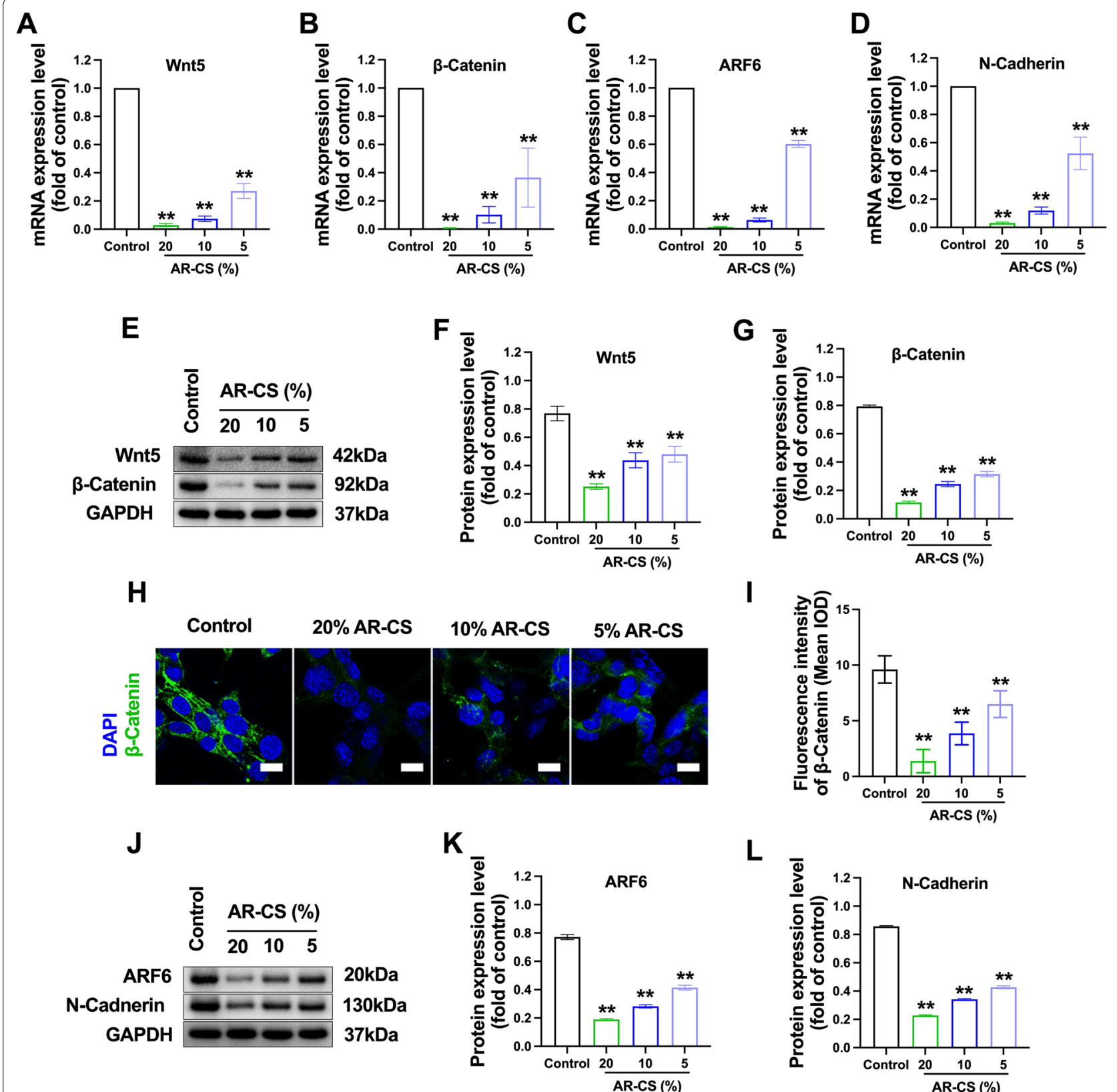

$\mathbf{L}$

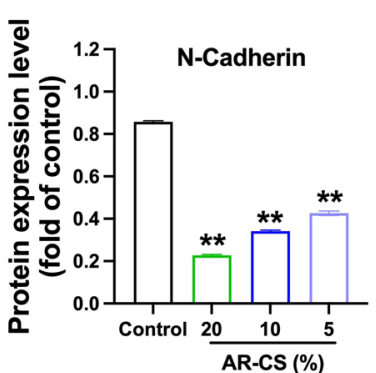

Fig. 3 AR-CS inhibits Wnt/ $\beta$-Catenin signaling and EMT of SW620 cells. Different concentrations of AR-CS (0\%, 20\%, 10\%, 5\%) treated SW620 cells for $24 \mathrm{~h}$, real-time qPCR was used to detect Wnt5 (A), $\beta$-Catenin (B), ARF6 (C), and N-Cadherin (D) mRNA expression. Western blot was used to detect Wnt5 and $\beta$-Catenin protein expression $(\mathbf{E})$, Wnt5 $(\mathbf{F})$ and $\beta$-Catenin $(\mathbf{G})$ protein expression level was normalized to control group. Immunofluorescent staining was used to detect $\beta$-Catenin expression $(\mathbf{H})$ and the fluorescence density was calculated $(\mathbf{I})$. Scale bar $=20 \mu \mathrm{m}$. Western blot was used to detect ARF6 and N-Cadherin protein expression (J), ARF6 (K) and N-Cadherin (L) protein expression level was normalized to control group. $N=6$, compared with the control group, ${ }^{* *} p<0.01$

Wnt 5 or $\beta$-Catenin significantly increased the mRNA level and protein level of ARF6 and N-Cadherin (Fig. 4C, D, F, I, J), and also promoted the proliferation and migration of SW620 cells (Fig. 4K-N). The results of $20 \%$ AR-CS in the WT-type SW620 here repeatedly confirmed the inhibitory effect of AR-CS on the mRNA levels and protein levels of Wnt5, $\beta$-Catenin, ARF6 and N-Cadherin (Fig. 4A-J), and its inhibitory effect on the proliferation and migration of SW620 cells (Fig. 4K-N). Compared with WT-type SW620 cells, in cells with overexpression of Wnt5 or $\beta$-Catenin, the inhibitory effect of $20 \%$ 

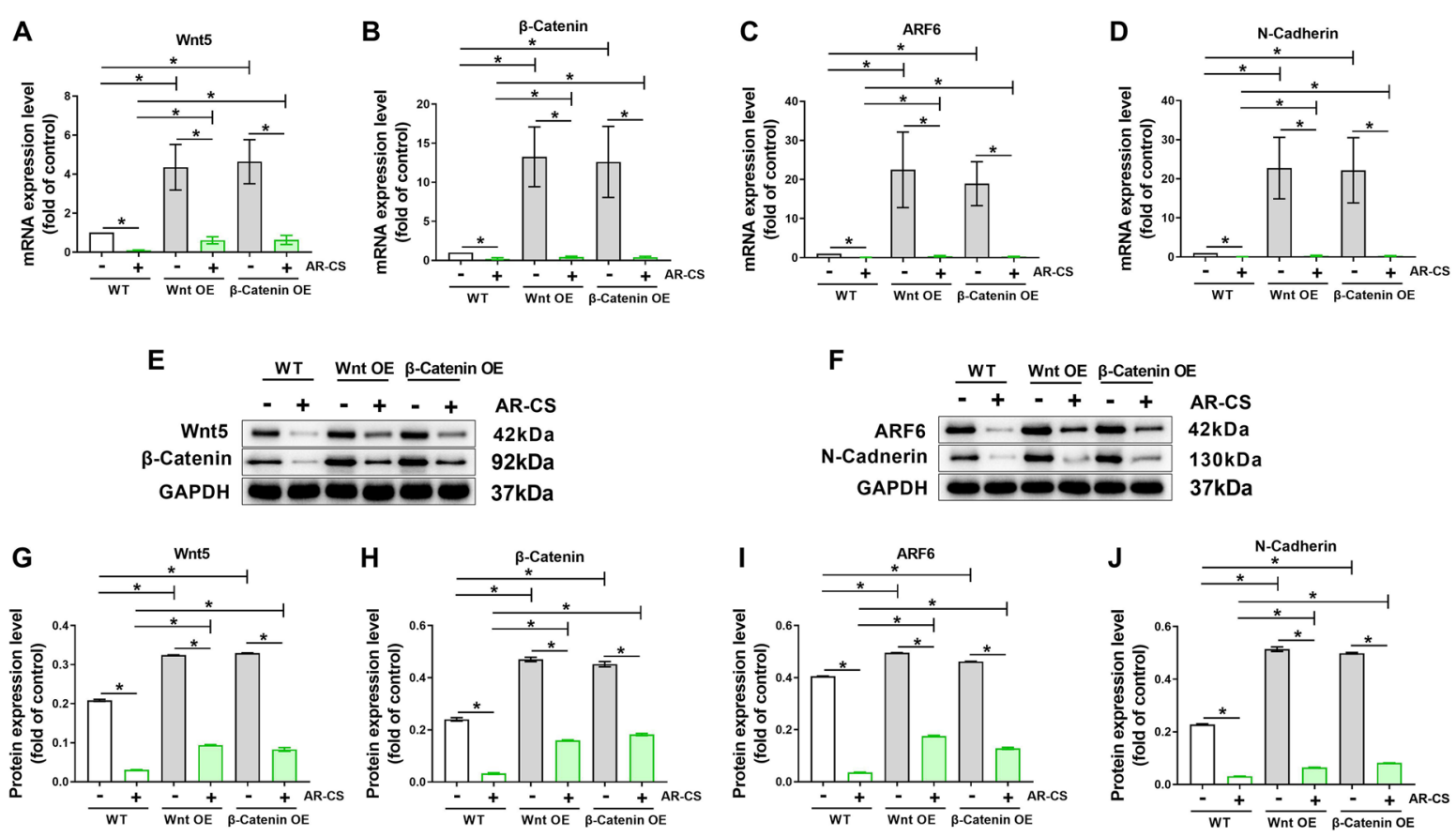

K
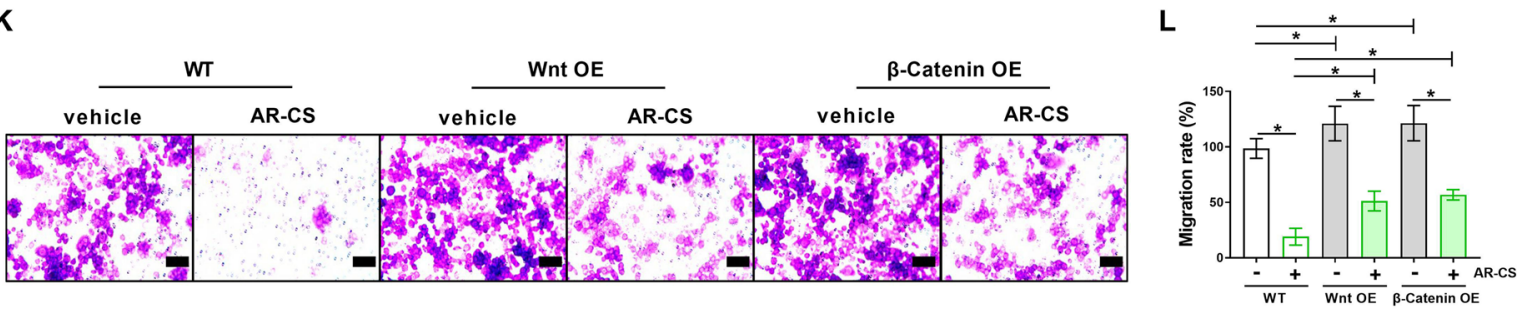

$\mathbf{N}$
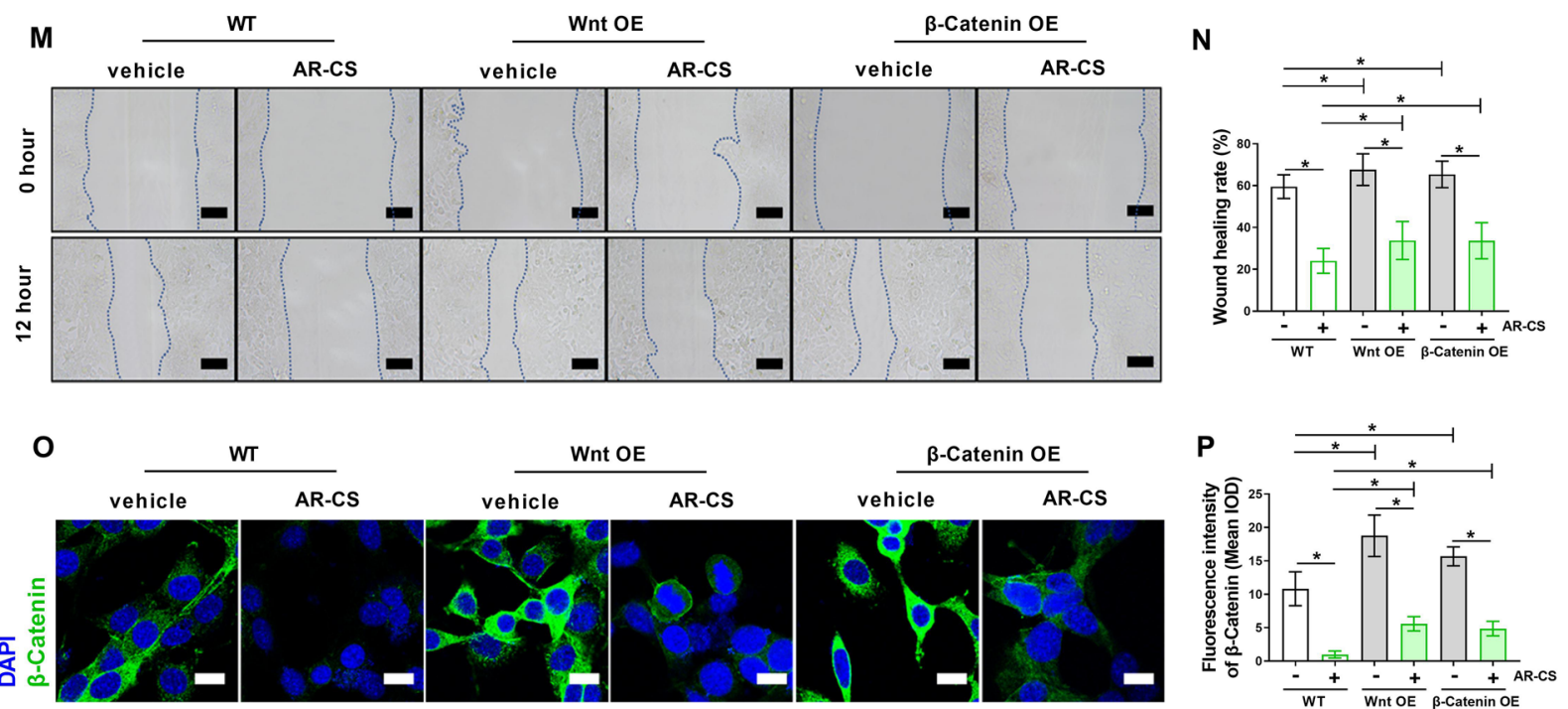

Fig. 4 Overexpression of Wnt5 or $\beta$-Catenin eliminates the inhibition ability of AR-CS in proliferation and migration of SW620 cells. WT, Wnt5 over-expressed, and $\beta$-Catenin over-expressed SW620 cells with or without 20\% AR-CS treated for $24 \mathrm{~h}$, real-time qPCR was used to detect Wnt5 (A), $\beta$-Catenin (B), ARF6 (C), and N-Cadherin (D) mRNA expression. Western blot was used to detect Wnt5, $\beta$-Catenin (E), ARF6, and N-Cadherin (F) protein expression. Wnt5 (G), $\beta$-Catenin (H), ARF6 (I), and N-Cadherin (J) protein expression level was normalized to control group. Transwell assay (K) was used to detect cell migration rate $(\mathbf{L})$. Wound scratch assay $(\mathbf{M})$ was used to detect cell wound healing rate $(\mathbf{N})$. Immunofluorescent staining was used to detect $\beta$-Catenin expression $(\mathbf{O})$ and the fluorescence density was calculated $(\mathbf{P})$. Scale bar $=100 \mu \mathrm{m}$ in $\mathbf{K}$, Scale bar $=400 \mu \mathrm{m}$ in $\mathbf{M}$, Scale bar $=20 \mu \mathrm{m}$ in $\mathbf{O} . \mathbf{N}=6$, in indicating comparison, ${ }^{*} p<0.05$ 
AR-CS on the mRNA level and protein level of Wnt5, $\beta$-Catenin, ARF6 and N-Cadherin was partially reversal (Fig. 4A-J), and the inhibitory effect of AR-CS on the proliferation and migration of SW620 cells was greatly weakened (Fig. $4 \mathrm{~K}-\mathrm{N})$. $\beta$-Catenin expression was retested using immunofluorescence, and the fluorescence intensity of $\beta$-Catenin showed consistent changes with western blot results in WT, Wnt 5 overexpressed, and $\beta$-Catenin over-expressed SW620 cells with or without $20 \%$ AR-CS treatment (Fig. 4 O, P).

\section{Knock-down of Wnt 5 or $\beta$-Catenin promotes the inhibition ability of AR-CS in proliferation and migration of SW620 cells}

To further clarify the role of Wnt/ $\beta$-Catenin signaling in AR-CS inhibiting the proliferation and migration of SW620 cells, Wnt 5 or $\beta$-Catenin siRNA was used to knock-down the mRNA level of Wnt 5 or $\beta$-Catenin in SW620 cells (Fig. 5A, B), Western blot results showed that knock-down of Wnt 5 or $\beta$-Catenin significantly reduced the protein level of Wnt 5 or $\beta$-Catenin in SW620 cells (Fig. 5E, G, H). Compared with WTtype SW620, knockdown of Wnt5 or $\beta$-Catenin significantly reduced the mRNA and protein levels of ARF6 and N-Cadherin in SW620 cells (Fig. 5C, D, F, I, J), while inhibiting the proliferation and migration of SW620 cells (Fig. 5K-N). The results of $20 \%$ AR-CS in the WT-type SW620 here repeatedly for the third time confirmed the inhibitory effect of AR-CS on the mRNA and protein levels of Wnt $5, \beta$-Catenin, ARF6 and N-Cadherin (Fig. 5A-J), and its inhibitory effect on the proliferation and migration of SW620 cells (Fig. 5K-N). Compared with WT-type SW620 cells, in Wnt 5 or $\beta$-Catenin knockdown cells, the inhibitory effect of $20 \%$ AR-CS on the mRNA and protein levels of Wnt 5, $\beta$-Catenin, ARF6 and N-Cadherin was enhanced (Fig. 5A-J), and the inhibitory effect of AR-CS on the proliferation and migration of SW620 cell was enhanced (Fig. $5 \mathrm{~K}-\mathrm{N}$ ). $\beta$-Catenin expression was retested using immunofluorescence, and the fluorescence intensity of $\beta$-Catenin showed consistent changes with western blot results in WT, Wnt5 knockdown, and $\beta$-Catenin knock-down SW620 cells with or without 20\% AR-CS treatment (Fig. 5O, P).

\section{Wnt 5 or $\beta$-Catenin inhibitor promotes the inhibition ability of AR-CS in proliferation and migration of SW620 cells}

Wnt 5 inhibitor (IWP-4), or $\beta$-Catenin inhibitor (JW55) alone or together with AR-CS verified the above results. After incubating SW620 cells with IWP-4 or JW55 for $24 \mathrm{~h}$, the mRNA and protein levels of Wnt 5 or $\beta$-Catenin were significantly reduced. At the same time, the mRNA and protein levels of ARF6 and N-Cadherin, and the proliferation and migration of SW620 cells were also reduced (Fig. 6A-J). Futhermore, AR-CS incubated with IWP-4 or JW55 increased the mRNA and protein levels of Wnt 5, $\beta$-Catenin, ARF6 and N-Cadherin, compared with the AR-CS alone group (Fig. 6A-J). The inhibitory effect of AR-CS on the proliferation and migration of SW620 cells was also enhanced by Wnt 5 inhibitor (IWP4), or $\beta$-Catenin inhibitor (JW55) (Fig. 6K-N). $\beta$-Catenin expression was retested using immunofluorescence, and the fluorescence intensity of $\beta$-Catenin showed consistent changes with western blot results in SW620 cells with or without $20 \%$ AR-CS, Wnt5 inhibitor (IWP-4), and $\beta$-Catenin inhibitor (JW55) treatment (Fig. 6O, P).

\section{AR decoction inhibits tumor growth in nude mouse xenograft model}

After confirming that AR-CS can reduce proliferation and migration of SW620 cells by inhibiting Wnt $5 / \beta$-Catenin, we further verified the effect of AR decoction on tumor growth in vivo. Nude mice were injected subcutaneously with SW620 cells to replicate xenograft tumor mouse models, and AR decoction was given daily for 21 days after inoculation. Continuous weight data showed that neither AR decoction nor the positive control drug oxaliplatin had a significant effect on the body weight of xenograft mice (Fig. 7A). Continuous measurement of tumor volume showed that AR decoction or oxaliplatin significantly reduced the tumor volume of xenograft mice from 9 days treatment (Fig. 7B). In model mice treated with AR decoction or Oxaliplatin, the weight of the tumor was significantly reduced (Fig. 7C, D), and the protein levels of Wnt $5, \beta$-Catenin, ARF6 and N-Cadherin in the tumor were significantly down-regulated (Fig. 7E). Moreover, the protein levels of LRP5, LRP6, TCF-4, and LEF1 in the tumor were also significantly down-regulated by AR decoction or oxaliplatin treatment in xenograft mice

(See figure on next page.)

Fig. 5 Knock-down of Wnt5 or $\beta$-Catenin promotes the inhibition ability of AR-CS in proliferation and migration of SW620 cells. WT, Wnt5 knock-down, and $\beta$-Catenin knock-down SW620 cells with or without 20\% AR-CS treated for $24 \mathrm{~h}$, real-time qPCR was used to detect Wnt5 (A), $\beta$-Catenin (B), ARF6 (C), and N-Cadherin (D) mRNA expression. Western blot was used to detect Wnt5, $\beta$-Catenin (E), ARF6, and N-Cadherin (F) protein expression. Wnt5 (G), $\beta$-Catenin $(\mathbf{H})$, ARF6 (I), and N-Cadherin (J) protein expression level was normalized to control group. Transwell assay (K) was used to detect cell migration rate $(\mathbf{L})$. Wound scratch assay $(\mathbf{M})$ was used to detect cell wound healing rate $(\mathbf{N})$. Immunofluorescent staining was used to detect $\beta$-Catenin expression $(\mathbf{O})$ and the fluorescence density was calculated $(\mathbf{P})$. Scale bar $=100 \mu \mathrm{m}$ in $\mathbf{K}$, Scale bar $=400 \mu \mathrm{m}$ in $\mathbf{M}$, Scale bar $=20 \mu \mathrm{m}$ in $\mathbf{O} . \mathrm{N}=6$, in indicating comparison, ${ }^{*} \mathrm{p}<0.05$ 

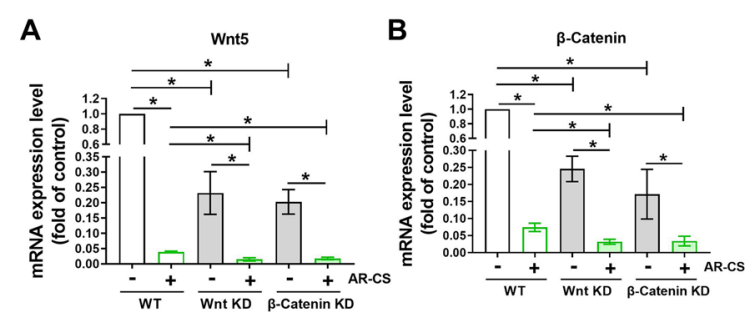

E
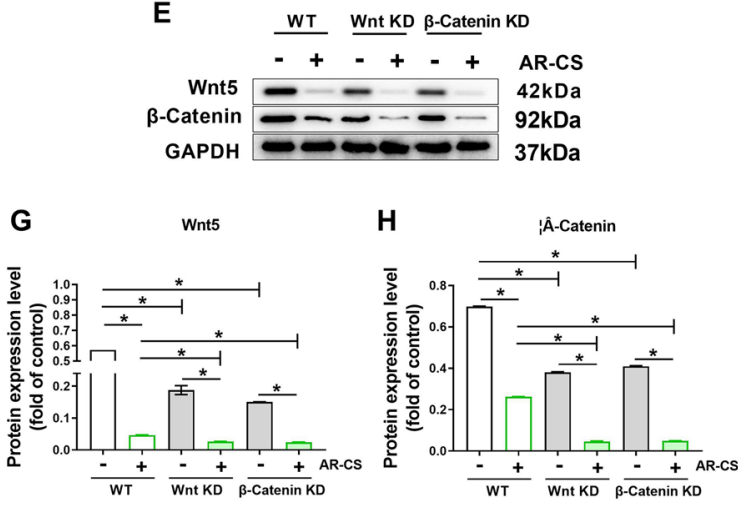

K
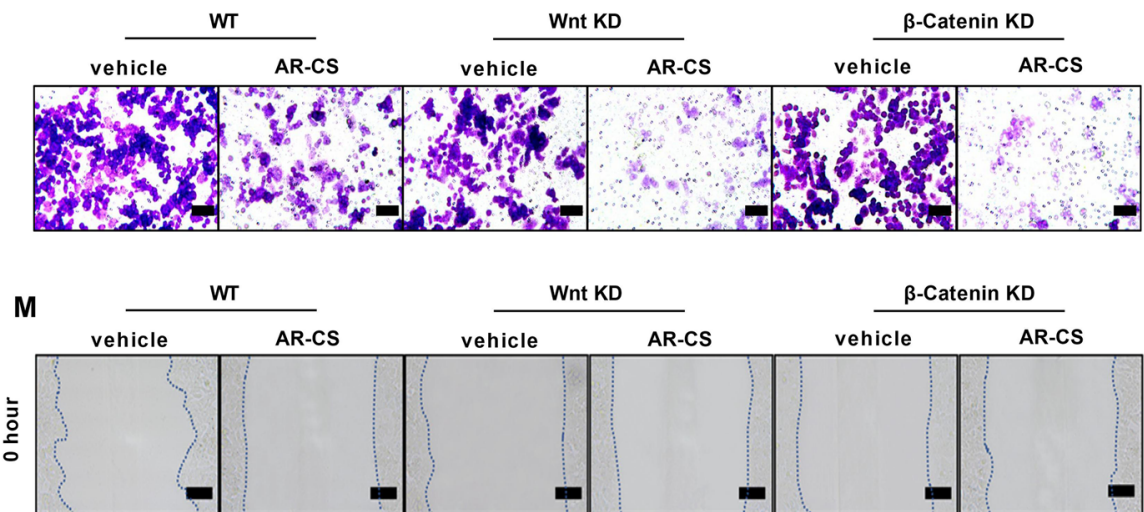

ำ

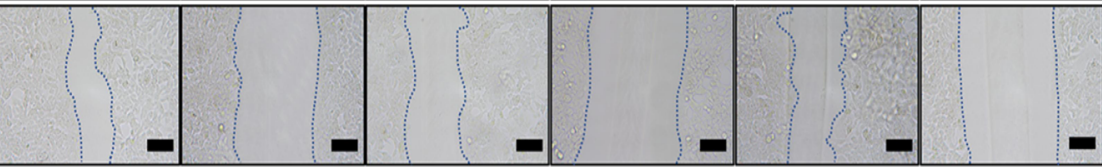

0

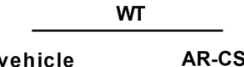

AR-CS
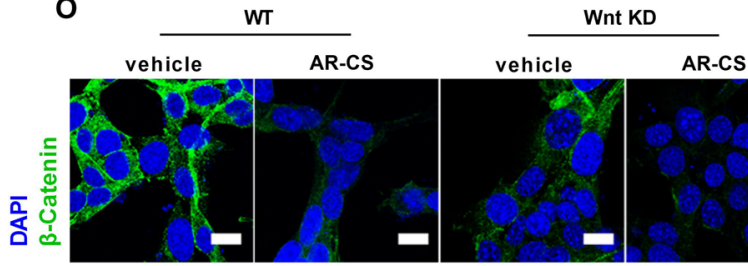

Fig. 5 (See legend on previous page.)
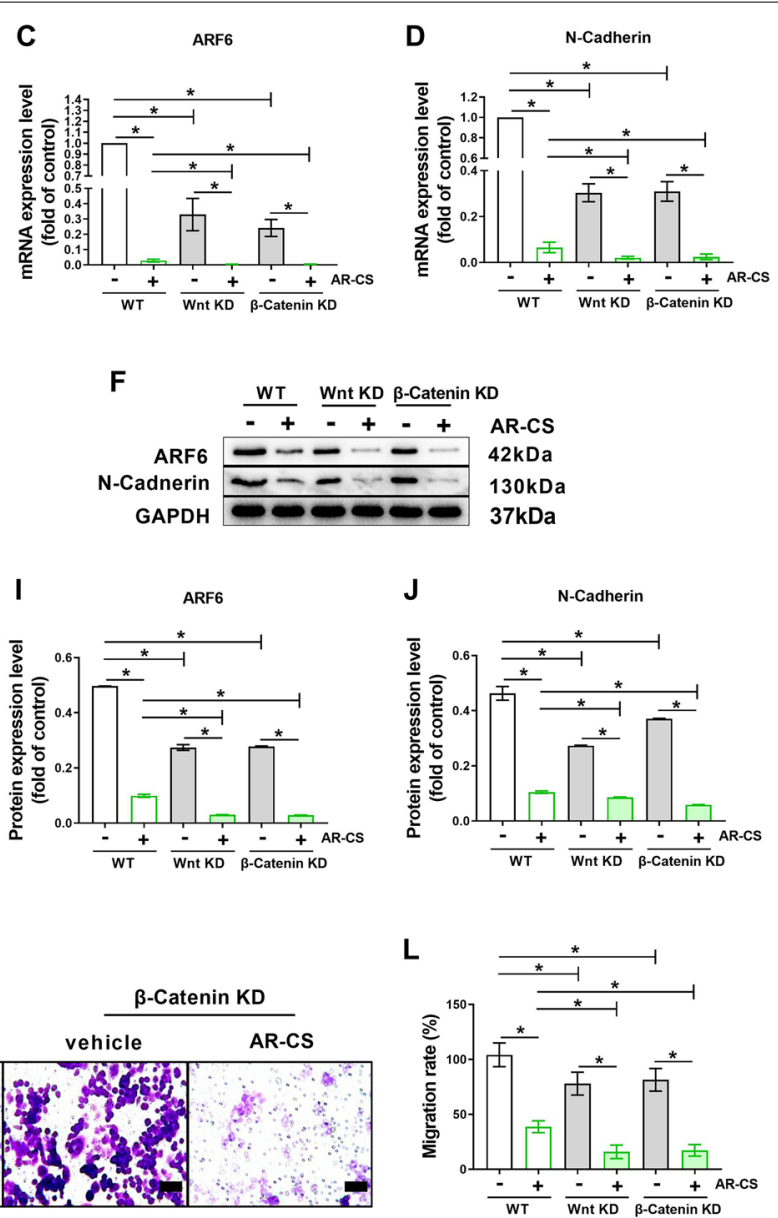

$\mathbf{N}$
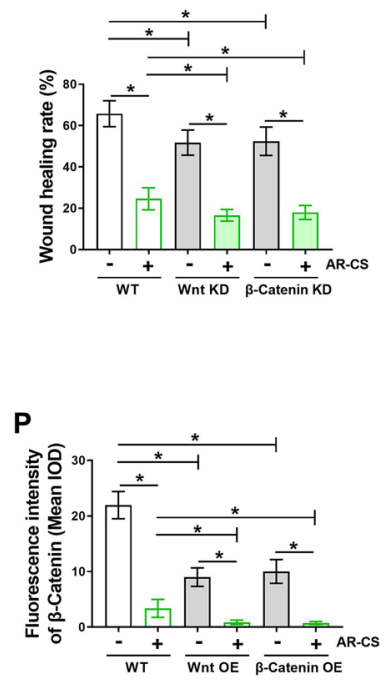
(Fig. 7F). In the HE section of the tumor, it can be seen that AR decoction or Oxaliplatin treatment caused cell apoptosis in the tumor tissue (Fig. 7G). The results of HE staining of the kidney and liver showed that AR decoction or Oxaliplatin treatment did not cause pathological damage to the kidney and liver (Fig. 7H). Blood biochemistry tests showed that AR decoction or oxaliplatin had no influence in serum Cr, BUN, AST, and ALT in xenograft mice (Fig. 7I-L).

\section{Discussion}

Here we report a traditional Chinese medicine AR decoction to treat colorectal cancer by inhibiting Wnt5/ $\beta$ Catenin signaling. In fact, traditional Chinese medicine have been used in the treatment of clinical tumors for many years [27], not only colon cancer [28], but also a variety of cancers, including breast cancer [29], glioblastoma [30], and pancreatic cancer [31]. Arsenic trioxide derived from traditional medicine has achieved exciting results in the treatment of leukemia [32]. The AR decoction explored in our current research has been used in clinical practice in China to treat CRC, but the unclear mechanism limits its clinical use. In the current study, we have provided evidence of AR decoction in the treatment of CRC in vitro and in vivo, and confirmed that Wnt $5 / \beta$-Catenin signaling plays an important role in this process.

The Wnt protein family plays a key role in tumor development through the classic Wnt/ $\beta$-catenin pathway, or the non-canonical pathway independent of $\beta$-catenin [33]. The Wnt signaling pathway is composed of functional proteins, enzymes, transcriptional regulatory factors, etc. Among them, $\beta$-catenin is a multifunctional protein involved in cell adhesion and signal transduction, and is a key component of the Wnt signaling pathway [34]. When the Wnt/ $\beta$-catenin pathway is activated, the Wnt ligand-related protein interacts with the receptor, resulting in the failure of the $\beta$-catenin polyprotein complex to form, and the increasing of free $\beta$-catenin protein level in the cytoplasm, then excessive $\beta$-Catenin enters the nucleus and interacts with nuclear transcription factors to initiate the transcription of Wnt pathway target genes and the expression of related proteins, including VEGF/E-cadherin/Cyclin-D1 [35], which leads to uncontrolled cell proliferation and decreased adhesion, angiogenesis, causing malignant proliferation, invasion and metastasis of tumor cells [36]. Study showed that Huangqi decoction improved renal tubulointerstitial fibrosis in mice by inhibiting $\mathrm{Wnt} / \beta$-catenin signaling pathway [37], and the extract of Huangqi and Ezhu inhibited the growth of Lewis lung cancer cells in xenograft mouse models by suppressing MAPK and VEGF signals [38]. Our present study showed AR decoction could inhibit tumor growth in mouse models of CRC xenograft tumors via inhibiting $\mathrm{Wnt} / \beta$-catenin signaling.

In the current study, first, we used AR-CS to interfere with SW620 cell line. After obtaining the appropriate intervention concentration and intervention time, it was confirmed that AR-CS could significantly inhibit the proliferation and migration of SW620 cells. We also confirmed that AR-CS inhibited the expression of Wnt 5 and $\beta$-catenin in SW620 cells in a concentrationdependent manner. In SW620 cells overexpressing Wnt5 or $\beta$-catenin, the inhibitory effect of AR-CS on the proliferation and migration of SW620 cells disappeared. Our research also showed that in SW620 cells, either knockdown of Wnt 5 alone, $\beta$-catenin alone, or use of Wnt 5 or $\beta$-catenin inhibitors directly inhibited the proliferation and migration of SW620 cells. As previously reported, inhibition of Wnt $5 / \beta$-catenin is an effective treatment for CRC $[20,39]$. When AR-CS was applied to Wnt 5 or $\beta$-catenin knock-down SW620 cells, or when AR-CS was used in combination with Wnt 5 or $\beta$-catenin inhibitors, the inhibitory effect of AR-CS on the proliferation and migration of SW620 cells was significantly enhanced, compared with WT-type SW620 or compared with SW620 cells treated with AR-CS alone. In summary, these results provide evidence that AR decoction inhibited the proliferation and migration of colorectal cancer cells by inhibiting Wnt $5 / \beta$-catenin.

In the process of AR-CS reducing the proliferation and migration of SW620 cells by inhibiting Wnt $5 / \beta$-catenin, our data also showed that the expression of ARF6 and N-Cadnerin in SW620 cells was significantly reduced by AR-CS. The small GTPase protein ARF6 has been proved to play a non-negligible role in promoting the proliferation, invasion and migration of a variety of tumor cells. By stimulating invasion ability, disrupting E-cadherinmediated cell adhesion, and inducing the recycling of $\beta$-catenin, the high expression of ARF6 promotes the

(See figure on next page.)

Fig. 6 Wnt5 or $\beta$-Catenin inhibitor promotes the inhibition ability of AR-CS in proliferation and migration of SW620 cells. SW620 cells were treated with or without 20\% AR-CS, Wnt5 inhibitor (IWP-4), and $\beta$-Catenin inhibitor (JW55) treated for $24 \mathrm{~h}$, real-time qPCR was used to detect Wnt5 (A), $\beta$-Catenin (B), ARF6 (C), and N-Cadherin (D) mRNA expression. Western blot was used to detect Wnt5, $\beta$-Catenin (E), ARF6, and N-Cadherin (F) protein expression. Wnt5 (G), $\beta$-Catenin $(\mathbf{H})$, ARF6 (I), and N-Cadherin (J) protein expression level was normalized to control group. Transwell assay (K) was used to detect cell migration rate $(\mathbf{L})$. Wound scratch assay $(\mathbf{M})$ was used to detect cell wound healing rate $(\mathbf{N})$. Immunofluorescent staining was used to detect $\beta$-Catenin expression $(\mathbf{O})$ and the fluorescence density was calculated $(\mathbf{P})$. Scale bar $=100 \mu \mathrm{m}$ in $\mathbf{K}$, Scale bar $=400 \mu \mathrm{m}$ in $\mathbf{M}$, Scale bar $=20 \mu \mathrm{m}$ in $\mathbf{O} . \mathrm{N}=6$, in indicating comparison, ${ }^{*} \mathrm{p}<0.05$ 

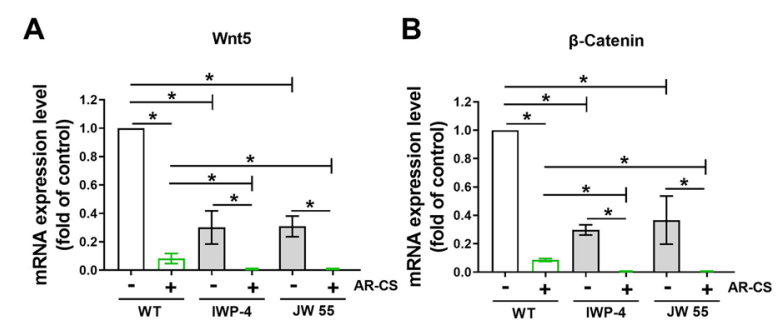

E
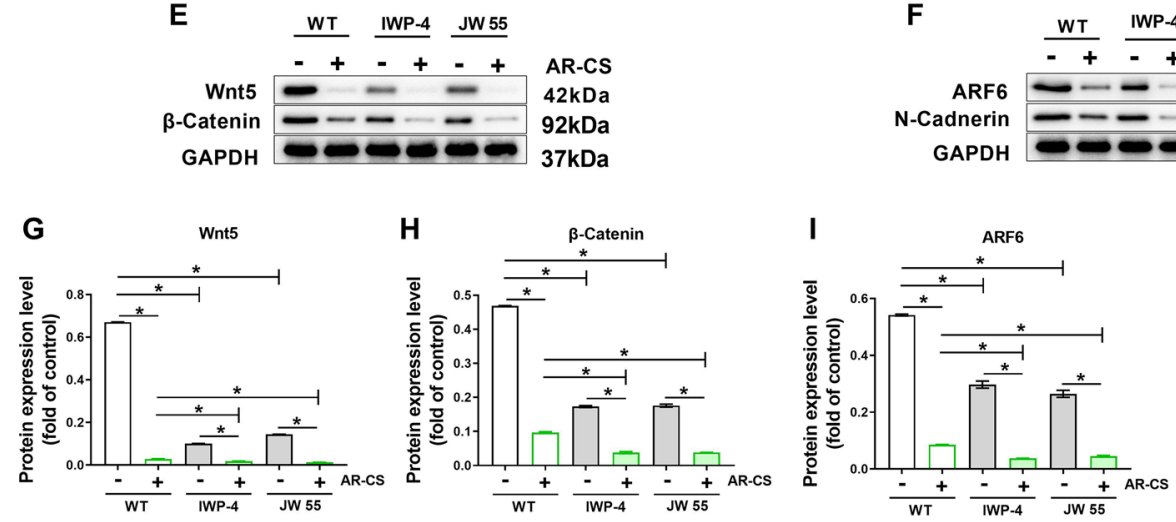

K
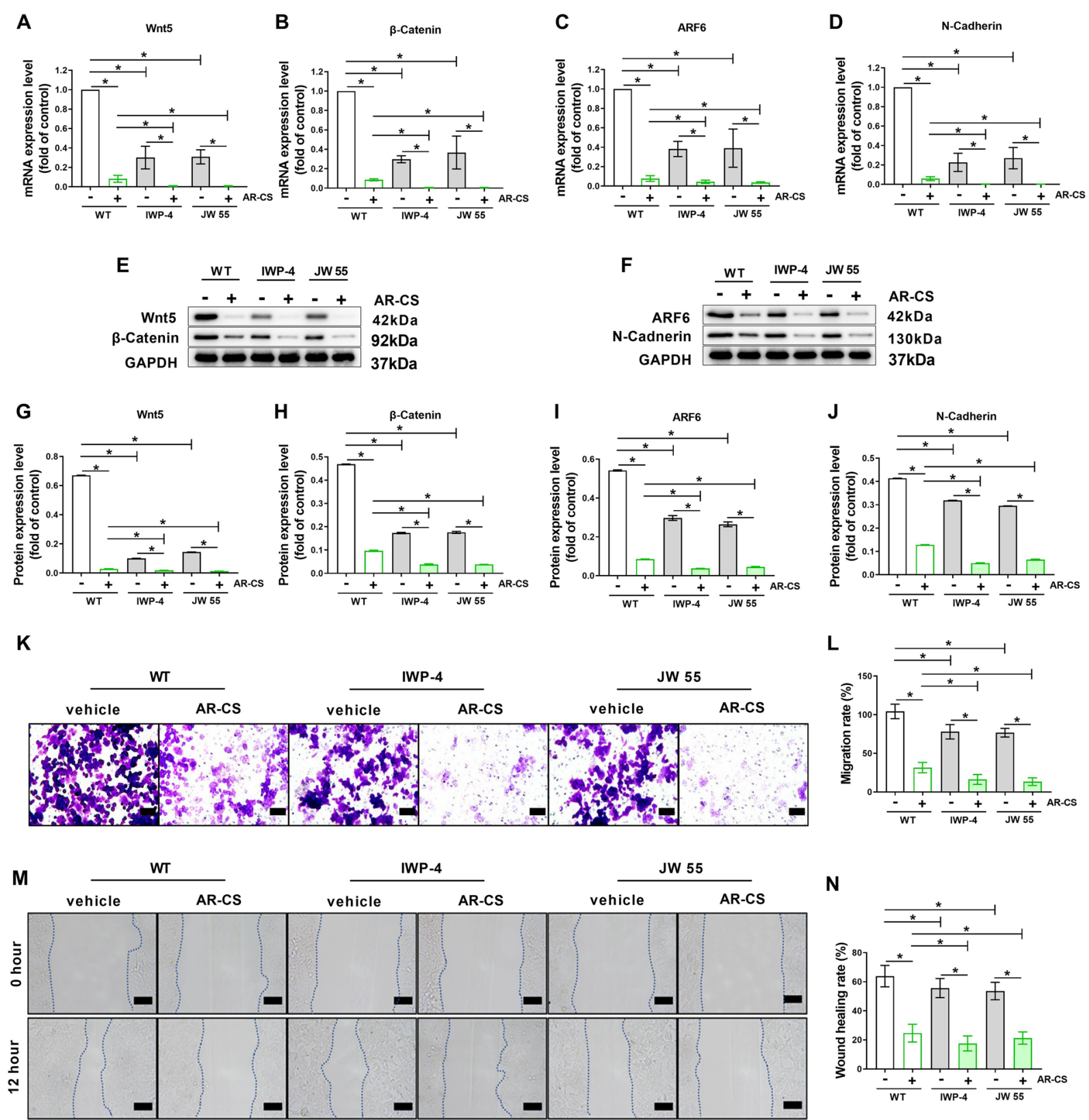

N

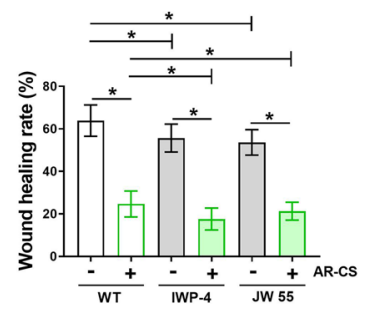

0
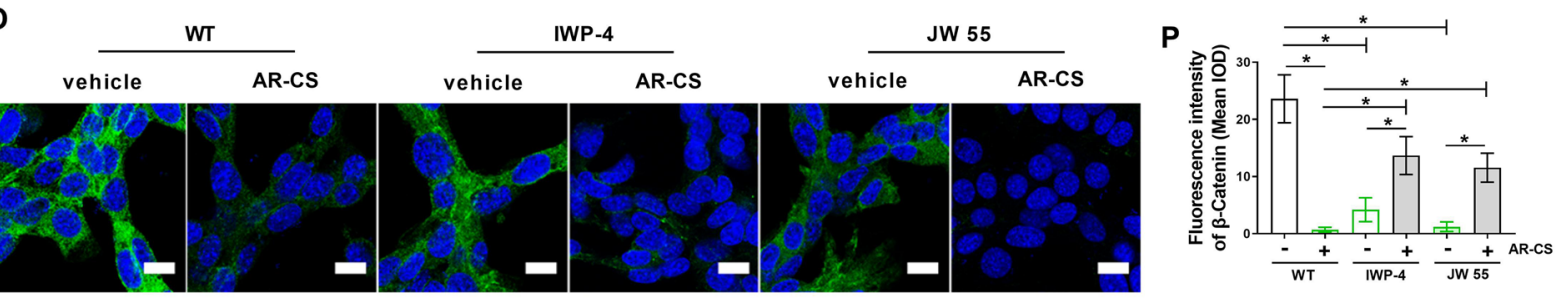

Fig. 6 (See legend on previous page.) 


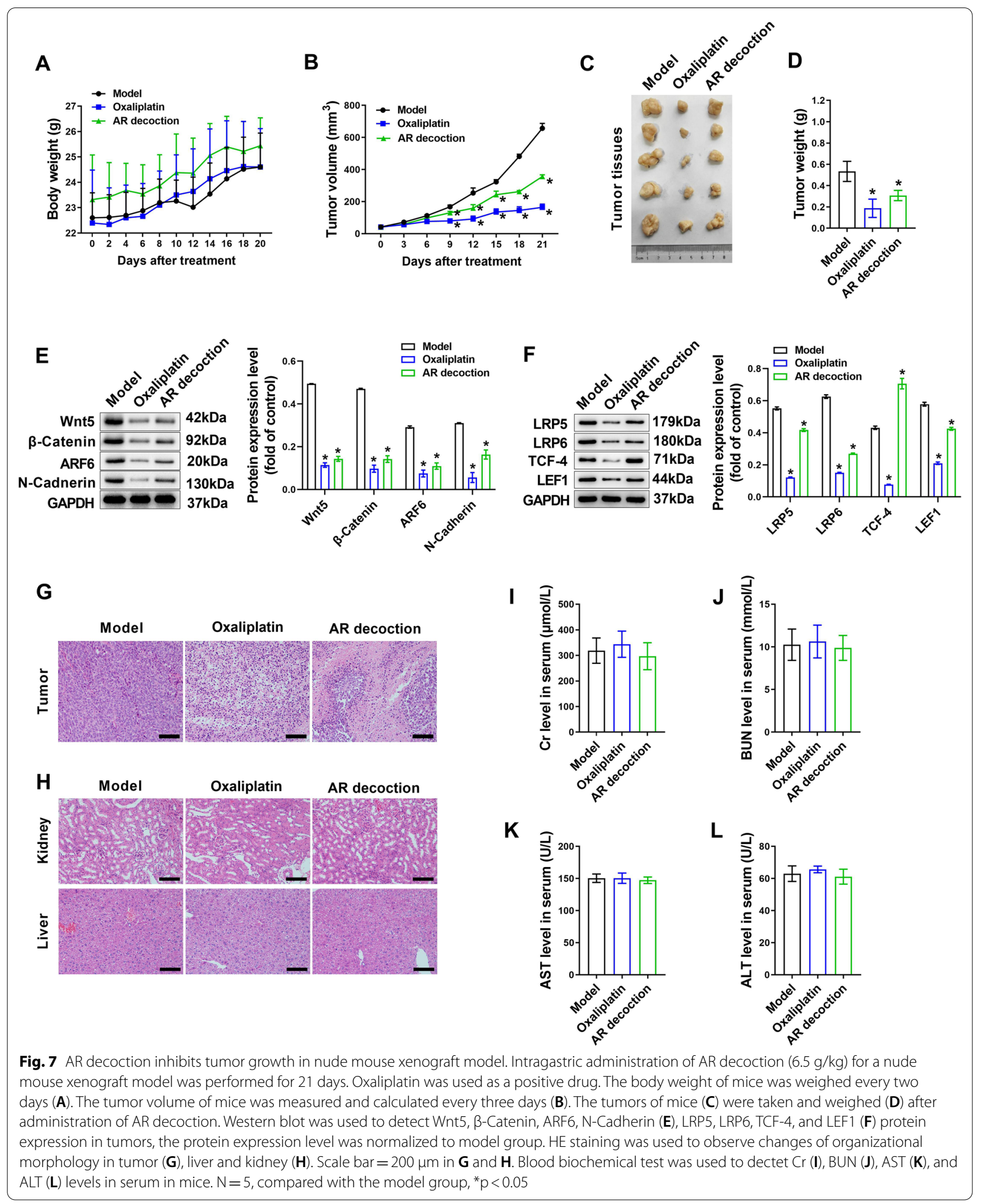


development of breast cancer, renal cell carcinoma, lung adenocarcinoma and colorectal cancer [40-42]. $\mathrm{N}$-cadherin is high expression in many tumors, including colorectal cancer [43]. Normal epithelial cells express E-cadherin, a cell adhesion molecule closely related to $\mathrm{N}$-cadherin [44]. Poorly differentiated cancer cells often no longer express E-cadherin, but show high expression of N-cadherin. A large number of studies have shown that the absence of E-cadherin and the abnormally high expression of $\mathrm{N}$-cadherin can cause tumor cells to lose polarity, resist apoptosis, and increase invasiveness and metastasis [45]. Inhibition of $\mathrm{N}$-cadherin has the potential to induce tumor cell apoptosis and inhibit metastasis [46].

When we applied AR-CS on SW620 cells overexpressing Wnt5 or $\beta$-catenin, the inhibitory effect of AR-CS on the expression of ARF6 and N-Cadnerin disappeared, indicating that the effect of AR-CS depended on Wnt5/ $\beta$ catenin signal. In SW620 cells, either knock-down of Wnt 5 alone, $\beta$-catenin alone, or use of Wnt 5 or $\beta$-catenin inhibitors directly inhibited the expression of ARF6 and $\mathrm{N}$-Cadnerin in SW620. And when we use AR-CS on Wnt 5 or $\beta$-catenin knock-down SW620 cells, or when AR-CS was combined with Wnt 5 or $\beta$-catenin inhibitors, the inhibitory effect of AR-CS on the expression of ARF6 and N-Cadnerin in SW620 cells was enhanced, compared with wild-type SW620 cells or compared with SW620 cells treated with AR-CS alone. Overall, the current results provide evidence that $A R$ decoction inhibits the expression of ARF6 and N-Cadnerin in colorectal cancer cells by inhibiting Wnt $5 / \beta$-catenin.

In this study, we also provided evidence that AR decoction inhibited tumor proliferation in CRC mice, and inhibited Wnt $5 / \beta$-catenin signaling and the expression of ARF6 and N-Cadnerin in tumors of CRC mice. More importantly, in vivo we performed protein expression detections of LRP5 and LRP6 which were associated with Wnt assembly [47], and protein expression detections of transcription factor TCF-4 and LEF1 which were regulated by $\beta$-catenin [6]. We confirmed that AR inhibits LRP5, LRP6, TCF-4, and LEF1 expression in vivo.

Some deficiencies of this research are still worthy of in-depth exploration, including the failure to explain in depth how AR decoction interacts with Wnt $5 / \beta$-catenin signals to treat $\mathrm{CRC}$; and the failure to collect solid tumor samples from CRC patients receiving AR decoction treatment in China to verify the changes in Wnt $5 / \beta$-catenin signal and the expression of ARF6 and N-Cadnerin in patients. Some studies have shown that Huangqi or Ezhu could promote the efficacy of chemotherapeutic drugs or reduce drug resistance in cancer treatment $[48,49]$. Whether AR decoction has these effects is another interesting line of research.

\section{Conclusion}

The present study provided evidence that AR decoction inhibits Wnt $5 / \beta$-catenin signaling and inhibits the development of CRC in vitro and in vivo. AR decoction is a promising traditional medicine in the clinical treatment of CRC.

\section{Acknowledgements \\ Not applicable.}

\section{Authors' contributions}

YB, GW and JZ: investigation, methodology, formal analysis, visualization, writing original draft, review and editing draft. GY and TL: methodology, resources, and data curation. LL and XY: investigation and visualization. WZ: conceptualization, review and editing draft. KN: resources, and data curation. DT and YY: conceptualization, supervision, project administration, funding acquisition. All authors read and approved the final manuscript.

\section{Funding}

This research was supported by National Natural Science Foundation of China (No. 81873021 and 82074035); the Innovative project of postgraduate training of Jiangsu province (No. KYCX20_1486) and Major project for science and technology development of traditional Chinese Medicine of Jiangsu province (No. 2020ZX01).

\section{Availability of data and materials}

Data will be available from the authors upon reasonable request and with permission of Yong Bian after submission of the thesis.

\section{Declarations}

Ethics approval and consent to participate

All procedures described in this study were performed in accordance to the guidelines of Institutional Animal Ethical Committee of Nanjing University of

Chinese Medicine and in accordance with the ethical standards established by Ethics Committee of Nanjing University of Chinese Medicine.

\section{Consent for publication}

We declare that the Publisher has the Author's permission to publish the relevant contribution.

\section{Competing interests}

The authors declare that they have no competing interests.

\section{Author details}

${ }^{1}$ Laboratory Animal Center, Nanjing University of Chinese Medicine, Nanjing 210023, China. ${ }^{2}$ Center of Experimental Animals, Sichuan Academy of Chinese Medicine Sciences, Chengdu 610041, China. ${ }^{3}$ School of Traditional Chinese Medicine and School of Integrated Chinese and Western Medicine, Nanjing University of Chinese Medicine, Nanjing 210023, China. ${ }^{4}$ Jiangsu Key Laboratory of Oral Diseases, Nanjing Medical University, Nanjing 211166, China. ${ }^{5}$ School of Pharmacy, Nanjing University of Chinese Medicine, Nanjing 210023, China.

Received: 1 August 2021 Accepted: 27 December 2021

Published online: 06 January 2022

\section{References}

1. McClelland RJ. Psychosocial sequelae of head injury — anatomy of a relationship. Br J Psychiatry. 1988;153:141-6. https://doi.org/10.1192/bjp. 153.2.141.

2. Torre LA, Bray F, Siegel RL, Ferlay J, Lortet-Tieulent J, Jemal A. Global cancer statistics, 2012. CA Cancer J Clin. 2015;65:87-108. https://doi.org/ 10.3322/caac.21262.

3. Bray F, Ferlay J, Soerjomataram I, Siegel RL, Torre LA, Jemal A. Global cancer statistics 2018: GLOBOCAN estimates of incidence and 
mortality worldwide for 36 cancers in 185 countries. CA Cancer J Clin. 2018;68:394-424. https://doi.org/10.3322/caac.21492.

4. Li W, Li C, Zheng H, Chen G, Hua B. Therapeutic targets of Traditional Chinese Medicine for colorectal cancer. J Tradit Chin Med. 2016;36:243-9. https://doi.org/10.1016/s0254-6272(16)30034-6.

5. Luo H, Vong CT, Chen H, Gao Y, Lyu P, Qiu L, et al. Naturally occurring anti-cancer compounds: shining from Chinese herbal medicine. Chin Med. 2019;14:48. https://doi.org/10.1186/s13020-019-0270-9.

6. Liu X, Huang Y, Zhang Y, Li X, Liu C, Huang S, et al. T-cell factor (TCF/ LEF1) binding elements (TBEs) of FasL (Fas ligand or CD95 ligand) bind and cluster Fas (CD95) and form complexes with the TCF-4 and b-catenin transcription factors in vitro and in vivo which result in triggering cell death and/or cell activation. Cell Mol Neurobiol. 2016;36:1001-13. https://doi.org/10.1007/s10571-015-0290-7.

7. Li S, Sun Y, Huang J, Wang B, Gong Y, Fang Y, et al. Anti-tumor effects and mechanisms of Astragalus membranaceus (AM) and its specific immunopotentiation: status and prospect. J Ethnopharmacol. 2020;258: 112797. https://doi.org/10.1016/j.jep.2020.112797.

8. Bi YH, Zhang LH, Chen SJ, Ling QZ. Antitumor mechanisms of curcumae rhizoma based on network pharmacology. Evid Based Complement Alternat Med. 2018;2018:4509892. https://doi.org/10.1155/2018/ 4509892.

9. Wu TH, Yeh KY, Wang CH, Wang H, Li TL, Chan YL, et al. The combination of Astragalus membranaceus and Angelica sinensis inhibits lung cancer and cachexia through its immunomodulatory function. J Oncol. 2019;2019:9206951. https://doi.org/10.1155/2019/9206951.

10. Xu C, Wang Y, Feng J, Qin L, Xu R, Dou Y. Effect of optimal combination of Huangqi (Radix Astragali Mongolici) and Ezhu (Rhizoma Curcumae Phaeocaulis) on proliferation and apoptosis of A549 lung cancer cells. J Tradit Chin Med. 2018;38:351-8.

11. Zhou R, Chen H, Chen J, Chen X, Wen Y, Xu L. Extract from Astragalus membranaceus inhibit breast cancer cells proliferation via PI3K/AKT/ mTOR signaling pathway. BMC Complement Altern Med. 2018;18:83. https://doi.org/10.1186/s12906-018-2148-2.

12. Yin $Y$, Feng $L$, Wang $L$, Ding $L$. The role of curcumae rhizoma-sparganii rhizoma medicated serum in epithelial-mesenchymal transition in the triple negative breast cancer: pharmacological role of CR-SR in the TBNC. Biomed Pharmacother. 2018;99:340-5. https://doi.org/10.1016/j. biopha.2017.11.139.

13. Wu CT, Tsai YT, Lai JN. Demographic and medication characteristics of traditional Chinese medicine users among colorectal cancer survivors: a nationwide database study in Taiwan. J Tradit Complement Med. 2017;7:188-94. https://doi.org/10.1016/j.jtcme.2016.07.001.

14. Sun R, Gu J, Chang X, Liu F, Liang Y, Yang X, et al. Metabonomics study on orthotopic transplantion mice model of colon cancer treated with Astragalus membranaceus-Curcuma wenyujin in different proportions via UPLC-Q-TOF/MS. J Pharm Biomed Anal. 2021;193: 113708. https:// doi.org/10.1016/j.jpba.2020.113708.

15. Sun RL, Tang DC, Gu JF. Study on intervention effect of Astragali Radix-Curcumae Rhizoma on growth and metastasis of colon cancer in orthotopic transplantation mice model of colon cancer. Zhongguo Zhong Yao Za Zhi. 2021;46:2267-75. https://doi.org/10.19540/j.cnki. cjcmm.20201207.402.

16. Clara JA, Monge C, Yang Y, Takebe N. Targeting signalling pathways and the immune microenvironment of cancer stem cells-a clinical update. Nat Rev Clin Oncol. 2020;17:204-32. https://doi.org/10.1038/ s41571-019-0293-2.

17. Faroogi AA, de la Roche M, Djamgoz MBA, Siddik ZH. Overview of the oncogenic signaling pathways in colorectal cancer: mechanistic insights. Semin Cancer Biol. 2019:58:65-79. https://doi.org/10.1016/j. semcancer.2019.01.001

18. Hansen CG, Moroishi T, Guan KL. YAP and TAZ: a nexus for Hippo signaling and beyond. Trends Cell Biol. 2015;25:499-513. https://doi.org/10. 1016/j.tcb.2015.05.002.

19. Yan KS, Janda CY, Chang J, Zheng GXY, Larkin KA, Luca VC, et al. Nonequivalence of Wnt and R-spondin ligands during Lgr5(+) intestinal stem-cell self-renewal. Nature. 2017;545:238-42. https://doi.org/10. 1038/nature22313.

20. Shang $\mathrm{S}$, Hua F, Hu ZW. The regulation of beta-catenin activity and function in cancer: therapeutic opportunities. Oncotarget. 2017;8:33972-89. https://doi.org/10.18632/oncotarget.15687.
21. Qin CJ, Bu PL, Zhang Q, Chen JT, Li QY, Liu JT, et al. ZNF281 regulates cell proliferation, migration and invasion in colorectal cancer through Wnt/ beta-Catenin signaling. Cell Physiol Biochem. 2019;52:1503-16. https:// doi.org/10.33594/000000104.

22. Wang Y, Xie C, Li Q, Xu K, Wang E. Clinical and prognostic significance of Yes-associated protein in colorectal cancer. Tumour Biol. 2013;34:216974. https://doi.org/10.1007/s13277-013-0751-x.

23. Li N, Xi Y, Tinsley HN, Gurpinar E, Gary BD, Zhu B, et al. Sulindac selectively inhibits colon tumor cell growth by activating the CGMP/PKG pathway to suppress Wnt/beta-catenin signaling. Mol Cancer Ther. 2013;12:1848-59. https://doi.org/10.1158/1535-7163.MCT-13-0048.

24. Guo S, Shen QN, Cao HH, Li P, Zhang KW, Xie H, et al. Study on quality of standard decoction of Coptidis Rhizoma based on traditional decoction process. Zhongguo Zhong Yao Za Zhi. 2019;44:3985-93. https://doi.org/ 10.19540/j.cnki.cjcmm.20190630.303.

25. Qin MY, Huang SQ, Zou XQ, Zhong XB, Yang YF, Zhang YT, et al. Drugcontaining serum of rhubarb-astragalus capsule inhibits the epithelialmesenchymal transformation of HK-2 by downregulating TGF-beta1/ p38MAPK/Smad2/3 pathway. J Ethnopharmacol. 2021;280: 114414. https://doi.org/10.1016/j.jep.2021.114414.

26. Feldman AT, Wolfe D. Tissue processing and hematoxylin and eosin staining. Methods Mol Biol. 2014;1180:31-43. https://doi.org/10.1007/ 978-1-4939-1050-2_3.

27. Xiang Y, Guo Z, Zhu P, Chen J, Huang Y. Traditional Chinese medicine as a cancer treatment: modern perspectives of ancient but advanced science. Cancer Med. 2019;8:1958-75. https://doi.org/10.1002/cam4.2108.

28. Aiello P, Sharghi M, Mansourkhani SM, Ardekan AP, Jouybari L, Daraei N, et al. Medicinal plants in the prevention and treatment of colon cancer. Oxid Med Cell Longev. 2019;2019:2075614. https://doi.org/10.1155/2019/ 2075614

29. Yang Z, Zhang Q, Yu L, Zhu J, Cao Y, Gao X. The signaling pathways and targets of traditional Chinese medicine and natural medicine in triplenegative breast cancer. J Ethnopharmacol. 2021;264: 113249. https://doi. org/10.1016/j.jep.2020.113249.

30. Wang J, Qi F, Wang Z, Zhang Z, Pan N, Huai L, et al. A review of traditional Chinese medicine for treatment of glioblastoma. Biosci Trends. 2020;13:476-87. https://doi.org/10.5582/bst.2019.01323.

31. Gao Y, Chen S, Sun J, Su S, Yang D, Xiang L, et al. Traditional Chinese medicine may be further explored as candidate drugs for pancreatic cancer: a review. Phytother Res. 2021;35:603-28. https://doi.org/10.1002/ptr.6847.

32. Hoonjan M, Jadhav V, Bhatt P. Arsenic trioxide: insights into its evolution to an anticancer agent. J Biol Inorg Chem. 2018;23:313-29. https://doi. org/10.1007/s00775-018-1537-9.

33. Cheng $X, X u X, C$, $n$ D, Zhao F, Wang W. Therapeutic potential of targeting the Wnt/beta-catenin signaling pathway in colorectal cancer. Biomed Pharmacother. 2019;110:473-81. https://doi.org/10.1016/j.biopha.2018. 11.082.

34. Zhang $Y$, Wang $X$. Targeting the Wnt/beta-catenin signaling pathway in cancer. J Hematol Oncol. 2020;13:165. https://doi.org/10.1186/ s13045-020-00990-3.

35. Bian J, Dannappel M, Wan C, Firestein R. Transcriptional regulation of Wnt/ beta-Catenin pathway in colorectal cancer. Cells. 2020. https://doi.org/10. 3390/cells9092125.

36. Nusse R, Clevers H. Wnt/beta-Catenin signaling, disease, and emerging therapeutic modalities. Cell. 2017;169:985-99. https://doi.org/10.1016/j. cell.2017.05.016.

37. Jiang MQ, Wang L, Cao AL, Zhao J, Chen X, Wang YM, et al. HuangQi decoction improves renal tubulointerstitial fibrosis in mice by inhibiting the up-regulation of wnt/beta-catenin signaling pathway. Cell Physiol Biochem. 2015;36:655-69. https://doi.org/10.1159/000430128.

38. Xu C, Wang Y, Feng J, Xu R, Dou Y. Extracts from Huangqi (Radix Astragali Mongoliciplus) and Ezhu (Rhizoma Curcumae Phaeocaulis) inhibit Lewis lung carcinoma cell growth in a xenograft mouse model by impairing mitogen-activated protein kinase signaling, vascular endothelial growth factor production, and angiogenesis. J Tradit Chin Med. 2019;39:559-65.

39. Bugter JM, Fenderico N, Maurice MM. Publisher correction: mutations and mechanisms of WNT pathway tumour suppressors in cancer. Nat Rev Cancer. 2021;21:64. https://doi.org/10.1038/s41568-020-00316-y.

40. Hashimoto S, Mikami S, Sugino H, Yoshikawa A, Hashimoto A, Onodera Y, et al. Lysophosphatidic acid activates Arf6 to promote the mesenchymal 
malignancy of renal cancer. Nat Commun. 2016;7:10656. https://doi.org/ 10.1038/ncomms 10656.

41. Fontana R, Ranieri M, La Mantia G, Vivo M. Dual role of the alternative reading frame ARF protein in cancer. Biomolecules. 2019. https://doi.org/ 10.3390/biom9030087.

42. Bahrami A, Hassanian SM, Khazaei M, Gharib M, Rahmani M, Fiuji H, et al. The 9p21 locus as a potential therapeutic target and prognostic marker in colorectal cancer. Pharmacogenomics. 2018;19:463-74. https://doi. org/10.2217/pgs-2017-0096.

43. Casal Jl, Bartolome RA. Beyond N-Cadherin, relevance of cadherins 5, 6 and 17 in cancer progression and metastasis. Int J Mol Sci. 2019. https:// doi.org/10.3390/ijms20133373.

44. Blaschuk OW. Discovery and development of $\mathrm{N}$-cadherin antagonists. Cell Tissue Res. 2012;348:309-13. https://doi.org/10.1007/s00441-011-1320-5.

45. Blaschuk OW. N-cadherin antagonists as oncology therapeutics. Philos Trans R Soc Lond B Biol Sci. 2015;370:20140039. https://doi.org/10.1098/ rstb.2014.0039.

46. Quintanal-Villalonga A, Ferrer I, Guruceaga E, Cirauqui C, Marrugal A, Ojeda L, et al. FGFR1 and FGFR4 oncogenicity depends on n-cadherin and their co-expression may predict FGFR-targeted therapy efficacy. EBioMedicine. 2020;53: 102683. https://doi.org/10.1016/j.ebiom.2020. 102683.

47. Ren Q, Chen J, Liu Y. LRP5 and LRP6 in Wnt signaling: similarity and divergence. Front Cell Dev Biol. 2021;9: 670960. https://doi.org/10.3389/fcell. 2021.670960.

48. Chang HL, Kuo YH, Wu LH, Chang CM, Cheng KJ, Tyan YC, et al. The extracts of Astragalus membranaceus overcome tumor immune tolerance by inhibition of tumor programmed cell death protein ligand-1 expression. Int J Med Sci. 2020;17:939-45. https://doi.org/10.7150/ijms. 42978.

49. Zhong Z, Yu H, Wang S, Wang Y, Cui L. Anti-cancer effects of Rhizoma Curcumae against doxorubicin-resistant breast cancer cells. Chin Med. 2018;13:44. https://doi.org/10.1186/s13020-018-0203-z.

\section{Publisher's Note}

Springer Nature remains neutral with regard to jurisdictional claims in published maps and institutional affiliations.

Ready to submit your research? Choose BMC and benefit from:

- fast, convenient online submission

- thorough peer review by experienced researchers in your field

- rapid publication on acceptance

- support for research data, including large and complex data types

- gold Open Access which fosters wider collaboration and increased citations

- maximum visibility for your research: over $100 \mathrm{M}$ website views per year

At BMC, research is always in progress.

Learn more biomedcentral.com/submissions 